\title{
Pesticide Residues and Their Metabolites in Grapes and Wines from Conventional and Organic Farming System
}

\author{
Dana Schusterova (D), Jana Hajslova, Vladimir Kocourek (D) and Jana Pulkrabova *(D) \\ Department of Food Analysis and Nutrition, University of Chemistry and Technology Prague, Technicka 3, \\ 16628 Prague, Czech Republic; dana.schusterova@vscht.cz (D.S.); jana.hajslova@vscht.cz (J.H.); \\ vladimir.kocourek@vscht.cz (V.K.) \\ * Correspondence: jana.pulkrabova@vscht.cz; Tel.: +420-220-443-272
}

Citation: Schusterova, D.; Hajslova,

J.; Kocourek, V.; Pulkrabova, J.

Pesticide Residues and Their Metabolites in Grapes and Wines from Conventional and Organic Farming System. Foods 2021, 10, 307. https://doi.org/10.3390/ foods 10020307

Academic Editor: Angela Di Pinto

Received: 8 January 2021

Accepted: 27 January 2021

Published: 2 February 202

Publisher's Note: MDPI stays neutral with regard to jurisdictional claims in published maps and institutional affiliations.

Copyright: (C) 2021 by the authors Licensee MDPI, Basel, Switzerland. This article is an open access article distributed under the terms and conditions of the Creative Commons Attribution (CC BY) license (https:// creativecommons.org/licenses/by/ $4.0 /)$.

\begin{abstract}
In this study, the occurrence of pesticide residues and their metabolites in grapes and wines was investigated. A targeted analysis of 406 pesticide residues in 49 wine and grape samples from organic and conventional production were performed using the QuEChERS (Quick, Easy, Cheap, Effective, Rugged and Safe) extraction method, followed by ultra-high-performance liquid chromatography coupled with tandem mass spectrometry. Multiple residues ( $>4$ residues/sample) were detected in 22 tested samples. The most commonly detected residues were fungicides (e.g., boscalid) and insecticides (e.g., methoxyfenozide). An ultra-high-performance liquid chromatography-high resolution mass spectrometry method (UHPLC-(HR)MS) was used for screening of pesticide metabolites. We also provide a method and database for detecting pesticide metabolites (extending our previously published database to 49 metabolites originating from 25 pesticides). An introduced strategy of targeted screening of pesticide metabolites was applied for authentication of 27 organic grapes and wines. In total, 23 samples were free of quantifiable residues/detected metabolites or contained residues approved for organic production.
\end{abstract}

Keywords: pesticide metabolites; pesticide residues; grapes; wines; organic farming; targeted screening; UHPLC-(HR)MS/MS

\section{Introduction}

Grapes are among the most widely grown fruits worldwide, consumed both fresh and in the processed forms (wines, raisins). Approximately 50\% of grapes are used in wine production [1]. The vineyard yield as well as grape quality can be affected by various plant diseases and pests, including the gray mold (Botrytis cinerea), downy mildew (Plasmopara viticola), powdery mildew (Uncinula necator), and grape moth (Lobesia botrana). In conventional production, various plant protection products (PPP), especially fungicides and insecticides, are widely used for protecting grapevine. For example, pesticide preparations with active ingredients such as fenhexamid, boscalid, dimethomorph, iprovalicarb, penconazole (fungicides) or methoxyfenozide, imidacloprid (insecticides) are approved in the European Union and commonly used by growers [2-4]. Although the use of pesticides in grapevine production provides various benefits, the presence of pesticide residues in grapes and their possible transfer into wines rise health concerns [4].

The data in The 2018 European Union report on pesticide residues in food [5] clearly documents a wide use of pesticides in viniculture worldwide. For example, quantifiable pesticide residues were observed in more than $86 \%$ of grapes; moreover, multiple residues were reported in more than $68 \%$ of tested samples (in total 2181 table grape samples). These results were comparable with those from previous years; boscalid, ethephon, dimethomorph, dithiocarbamates and fenhexamid were the most commonly detected residues $[5,6]$.

Under these conditions, it is not surprisingly that consumers' demand for organic grapes and wines is continuously growing. Organic farming is aimed at avoiding the use of artificial pesticides and fertilizers, thus reducing possible impact on the environment. 
Also, consumers' dietary exposure to pesticide residues in organic food is fairly lowered compared to consumption of products from conventional farming in which the application of various pesticide preparations against the harmful organisms is a common agriculture practice. The plant protection products approved in organic production are listed in the Commission Regulation (EC) No. 889/2008 (Annex II) [7-9]. Generally, modern pesticides rapidly degrade after application. The levels of pesticide residues in the treated grapevine decrease relatively quickly undergoing various biotransformation reactions (e.g., oxidation, hydrolysis in phase I, or conjugation such as glycosylation in phase II), resulting in a number of various products. The use of most artificial pesticides is prohibited in organic production. Hence, the presence of metabolites of these chemicals in organic products could be utilized as a marker of an unauthorized pesticide application even if the parent pesticide is not detectable. The possible transfer of parent pesticides and their metabolites from grapes into wines makes this strategy potentially useful also for authentication of organic wines [10-12].

In most available studies, a two-step sample preparation procedure is usually used for extracting pesticide metabolites from grape samples. In the first step, metabolites are extracted using either a polar solvent, such as acetonitrile, methanol or their mixture with water; alternatively, the "Quick, Easy, Cheap, Effective, Rugged and Safe" (QuEChERS) method or liquid-solid extraction are widely used for isolation of pesticide metabolites from grape samples. In the second step, a clean-up by dispersive solid phase extraction is often performed, using sorbents such as primary secondary amines (PSA), octadecyl sorbent (C18) or graphitized carbon black (GCB) [13-17]. In the recent studies, solid-phase extraction using Hydrophilic-Lipophilic-Balanced (HLB) sorbent or direct injection were employed for isolation of pesticide metabolites from wine samples [18,19]. As pesticides are commonly transformed into more polar low volatility compounds not amenable for gas chromatography (GC) analysis, high-performance liquid chromatography coupled to mass spectrometry HPLC-MS (using various mass analyzers) represents the most suitable approach for analyzing pesticide metabolites [20,21].

In our previous study [11], the strategy based on the analysis of pesticide residues and their metabolites for authentication of organic products was presented. Here, we aimed to extend the database of pesticide metabolites occurring in grapes/wines and to analyze pesticide residues and their metabolites ("authentication") in samples from organic production collected at the markets.

\section{Materials and Methods}

\subsection{Chemicals and Reagents}

Certified standards of pesticides were obtained from Dr. Ehrenstorfer GmbH (Augsburg, Germany), Honeywell Fluka ${ }^{\mathrm{TM}}$ or Honeywell Riedel-de Haen ${ }^{\mathrm{TM}}$ (both Seelze, Germany). The purity of standards ranged from 90 to $99.9 \%$. Triphenyl phosphate (TPP) and nicarbazin (internal standards), HPLC-grade acetonitrile, LC-MS grade formic acid, ammonium formate and ammonium acetate were supplied by Sigma-Aldrich (St. Louis, MO, USA). Methanol was obtained from Merck (Darmstadt, Germany). Acetone p.a. and sodium chloride were purchased from Penta (Chrudim, Czech Republic). Anhydrous magnesium sulphate was obtained from Honeywell Fluka ${ }^{\mathrm{TM}}$. Deionized water $(18 \mathrm{M} \Omega)$ was produced using a Millipore Milli-Q system (Bedford, MA, USA).

Individual pesticides' stock solutions and internal standards were prepared in pure acetonitrile, methanol or acetone containing $1 \%$ formic acid $(v / v)$ (depending on the solubility of the pesticide standard). A composite standard solution in acetonitrile was prepared at $50,000 \mathrm{ng} / \mathrm{mL}$ (each) from individual stock solutions. The working standard mixtures (20-2000 ng/mL) used for matrix-matched calibration were prepared from stock solution by diluting with acetonitrile. All standard solutions were stored in a freezer at $-18{ }^{\circ} \mathrm{C}$. Certified standards of pesticide metabolites were not commercially available [11]. 


\subsection{Samples}

Table grapes and wines from both conventional and organic production were collected for the purposes of this study. The samples tested in this study were produced in both EU and non-EU countries, but all of them were purchased at Czech markets. Grapes and wines from organic production were labelled using the EU organic logo. Detailed information of the collected samples can be found in Table S1 in the Supplementary Materials.

Bottled wines were stored in the original packaging at $5{ }^{\circ} \mathrm{C}$. On the day of purchase, grape samples were immediately frozen (at $-18^{\circ} \mathrm{C}$ ) for $12 \mathrm{~h}$ and then homogenized using a laboratory blender. The overview of samples is shown in Table 1.

Table 1. The overview of analyzed samples.

\begin{tabular}{cccc}
\hline Sample Type & Total Sampled & Conventional & Organic \\
\hline grapes & \multirow{2}{*}{16} & 10 & 6 \\
(white/red) & & $(6 / 4)$ & $(4 / 2)$ \\
wines & 33 & 12 & 21 \\
(white/rose/red) & 3 & $(1 / 0 / 11)$ & $(11 / 4 / 6)$ \\
\hline
\end{tabular}

\subsection{Sample Preparation}

The procedure for isolation of parent pesticides and their metabolites was similar (QuEChERS method) as described in our previous study [11]. Briefly, homogenized grapes/wines $(10 \mathrm{~g})$ were weighed into $50 \mathrm{~mL}$ polypropylene centrifuge tubes, which was followed by the addition of $10 \mathrm{~mL}$ of acetonitrile. After shaking, a mixture of salts $(1 \mathrm{~g}$ of $\mathrm{NaCl}$ and $4 \mathrm{~g}$ of $\mathrm{MgSO}_{4}$ ) was added and the shaking process was repeated. Then, an internal standards mixture was added and the tubes were centrifuged. An aliquot of the supernatant was transferred into a vial for LC-MS analysis.

\subsection{LC-MS Parameters}

\subsubsection{Analysis of Pesticide Residues}

The analyses of 406 pesticide residues were performed using the ultra-high- performance liquid chromatograph Waters Acquity UPLC system coupled to a triple quadrupole tandem mass spectrometer Xevo TQ-S (both Waters, Milford, MA, USA) in electrospray positive (ESI+) and negative (ESI-) modes. Sample separation was performed using an Acquity UPLC HSS T3 analytical column $(100 \mathrm{~mm} \times 2.1 \mathrm{~mm}, 1.8 \mu \mathrm{m}$ particle size, Waters, Milford, MA, USA).

The column and autosampler temperature were maintained at $40{ }^{\circ} \mathrm{C}$ and $5{ }^{\circ} \mathrm{C}$, respectively. For compounds detected in the ESI + , mobile phases consisted of (A) water with $5 \mathrm{mM}$ ammonium formate and $0.1 \%(v / v)$ formic acid and $(\mathrm{B})$ methanol, respectively. For compounds detected in the ESI-, mobile phases were (A) water with $5 \mathrm{mM}$ ammonium acetate and (B) pure methanol. The gradient was the same in both polarities: the starting mobile phase composition was $10 \%$ of the organic phase (B) with a flow rate of $0.3 \mathrm{~mL} \cdot \mathrm{min}^{-1}$, which was linearly changed over $1 \mathrm{~min}$ to $50 \%(\mathrm{~B})$, along with the linear change of the flow rate to $0.35 \mathrm{~mL} \cdot \mathrm{min}^{-1}$. Then, the mobile phase was linearly changed from $50 \%$ to $95 \%$ (B) over the next $9 \mathrm{~min}$, along with a gradual increase of the flow rate from 0.35 to $0.45 \mathrm{~mL} \cdot \mathrm{min}^{-1}$. Over the next $1 \mathrm{~min}$, the mobile phase changed to $100 \%$ (B) and the flow rate increased from 0.45 to $0.6 \mathrm{~mL} \cdot \mathrm{min}^{-1}$; this composition was held for the next $2 \mathrm{~min}$. The column was subsequently reconditioned for $2 \mathrm{~min}$ in the starting mobile phase composition, i.e., $10 \%(\mathrm{~B})$, at a flow rate of $0.5 \mathrm{~mL} \cdot \mathrm{min}^{-1}$. Sample volumes injected in the positive and negative ESI modes were $2.5 \mu \mathrm{L}$ and $3 \mu \mathrm{L}$, respectively.

The mass spectrometer Xevo TQ-S (Waters, Milford, MA, USA) was operated in the multiple reaction monitoring (MRM) mode. Electrospray ionization was conducted in the positive and negative mode with the capillary voltages of $0.6 \mathrm{kV}$ and $-0.6 \mathrm{kV}$, respectively. The source and desolvation temperatures were $120^{\circ} \mathrm{C}$ and $350^{\circ} \mathrm{C}$, respectively. Nitrogen was used as the desolvation and cone gas, argon was used as the collision gas. 
The generated data were processed by MassLynx software (version 4.1, Waters, Milford, MA, USA).

\subsubsection{Analysis of Pesticide Metabolites}

The ultra-high-performance liquid chromatograph Agilent Infinity 1290 LC system coupled to Quadrupole-Time of Flight high resolution mass spectrometer (UHPLC-HRMS) Agilent Ion-Mobility Q-TOF 6560 (both Agilent Technologies, Santa Clara, CA, USA) in positive and negative ESI modes was used for the analyses of pesticide metabolites. Sample separation was performed using an Acquity UPLC HSS T3 analytical column (100 mm $\times$ $2.1 \mathrm{~mm}, 1.8 \mu \mathrm{m}$ particle size, Waters, Milford, MA, USA). The parameters of the UHPLCHRMS analysis were described in detail in the previous study [11].

\subsection{Detection and Identification of Pesticide Residues and Pesticide Metabolites}

Pesticide residues were identified on the basis of a combination of the retention time and detection of two MRM transitions (considering their ion ratio); those were previously acquired from pesticide reference standards. The identification criteria were in accordance with the requirements stated in the European Commission's guidance document SANTE/12682/2019 [22].

The strategy of detection and identification of pesticide metabolites was based on the calculated accurate mass, isotopic pattern matching and the accurate mass of MS/MS fragments. The acceptable mass error of potential elemental composition for quasi-molecular ions was $\pm 5 \mathrm{ppm}$. A detailed description can be found in the previous study [11].

\subsection{Method Validation}

The analytical method for analysis of pesticide residues in grapes and wines was validated. Recoveries, repeatabilities and limits of quantification were determined in accordance with the European Commission's guidance document "Analytical quality control and method validation procedures for pesticide residues analysis in food and feed" [22]. Validation samples were prepared by spiking of blank grape/wine samples with pesticide standards at 2 spiking levels $(0.002 \mathrm{mg} / \mathrm{kg}$ and $0.2 \mathrm{mg} / \mathrm{kg})$ in 6 replicates. Then, the samples were extracted following the procedure described in Section 2.3.

\subsection{Quality Control}

The analytical method for pesticide residue analysis is accredited and routinely performed according to the EN ISO/IEC 17025:2017 standard. The laboratory regularly participates in the official European Union Proficiency Testing Program to control and keep the quality and accuracy of results.

\section{Results and Discussion}

\subsection{Validation}

The presented method was validated for 406 pesticide residues in grapes and wines according to the European Commission's guidance document "Analytical quality control and method validation procedures for pesticide residues analysis in food and feed" [22]. Limits of quantification (LOQs) were determined in the range from 0.001 to $0.02 \mathrm{mg} / \mathrm{kg}$ in both tested commodities. For $98.8 \%$ of pesticides, LOQs $\leq 0.01 \mathrm{mg} / \mathrm{kg}$ were reached. Recovery study was performed in six replicates at each spiking level with good repeatability (1-20\%; expressed as relative standard deviation). At the level $0.002 \mathrm{mg} / \mathrm{kg}$, recoveries of 368 analytes were in the range $70-107 \%$ in grapes and 367 analytes in the range 70 $120 \%$ in wines. At the level $0.02 \mathrm{mg} / \mathrm{kg}$, recoveries of 406 analytes were in the range $71-116 \%$ in grapes and 399 analytes in the range $71-118 \%$ in wines. Table S2 in the Supplementary Materials summarizes the full list of performance characteristics for all analytes and both commodities. 


\subsection{Residues in Grapes and Wines from Conventional Production}

In this study, 10 grape and 12 wine samples from conventional production were analyzed. All tested samples contained quantifiable residues of more than one pesticide (see Figure 1). In total, 29 and 25 pesticide residues were detected in grapes and wines, respectively. The most frequently quantifiable pesticide residues in grape samples were boscalid (9 samples), with concentrations ranging from 0.009 to $1.07 \mathrm{mg} / \mathrm{kg}$. Penconazole and pyrimethanil were found in 5 samples, their concentrations were $0.002-0.044 \mathrm{mg} / \mathrm{kg}$ and $0.002-1.44 \mathrm{mg} / \mathrm{kg}$, respectively. In wine samples, the most often detected residues were those of fenhexamid, followed by iprovalicarb and boscalid. Measured concentrations were $0.003-0.086 \mathrm{mg} / \mathrm{kg}$ (fenhexamid), $0.002-0.059 \mathrm{mg} / \mathrm{kg}$ (iprovalicarb) and $0.001-0.056 \mathrm{mg} / \mathrm{kg}$ (boscalid). The detailed results are shown in Table 2. No exceedance of maximum residue levels (MRL) was found in any of the tested samples [23].

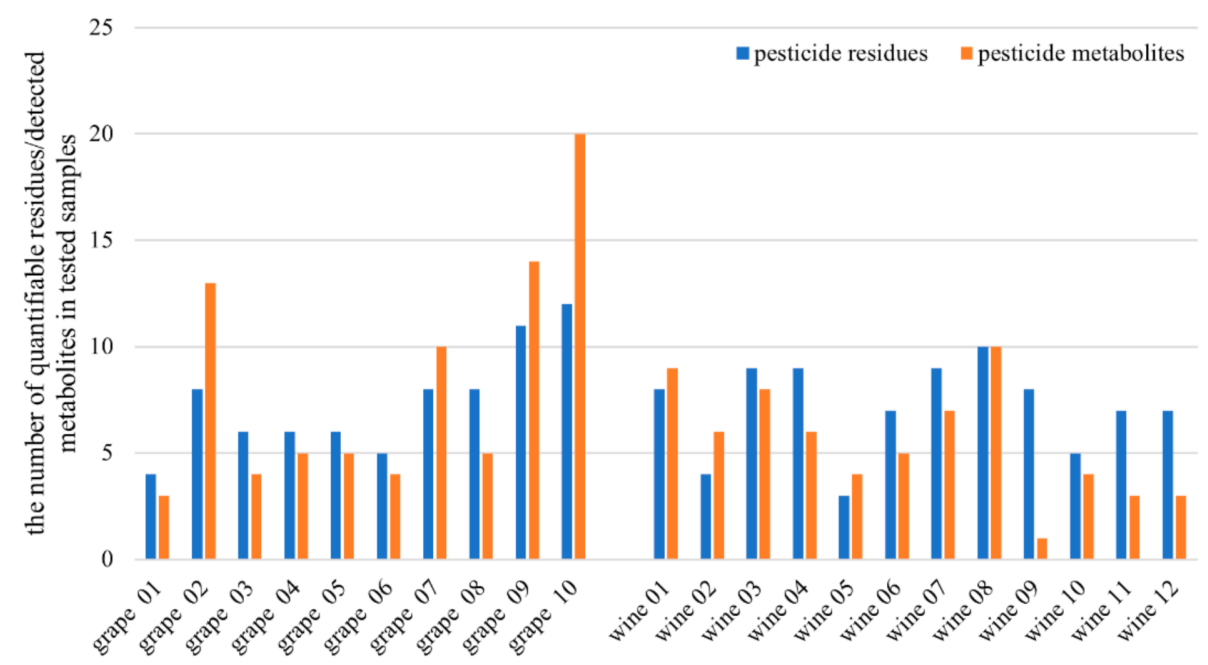

Figure 1. The number of quantifiable pesticide residues and detected pesticide metabolites in individual tested grapes and wines from conventional production.

Table 2. The limits of quantification, MRLs and minimum and maximum concentrations of detected pesticides in tested grapes and wines from conventional production.

\begin{tabular}{|c|c|c|c|c|c|c|c|c|c|}
\hline \multirow[b]{3}{*}{ Analyte $(f / i){ }^{1}$} & \multirow[b]{3}{*}{$\begin{array}{c}\text { LOQ } \\
{[\mathrm{mg} / \mathrm{kg}]}\end{array}$} & \multicolumn{4}{|c|}{ GRAPES } & \multicolumn{4}{|c|}{ WINES } \\
\hline & & \multicolumn{4}{|c|}{ Concentration of Residues [mg/kg] } & \multicolumn{4}{|c|}{ Concentration of Residues [mg/kg] } \\
\hline & & $\mathbf{N}$ & Minimum & Maximum & MRL $^{2}$ & $\mathbf{N}$ & Minimum & Maximum & MRL $^{3}$ \\
\hline acetamiprid (i) & 0.001 & 2 & 0.076 & 0.138 & 0.5 & 0 & 0 & 0 & 0.5 \\
\hline ametoctradin (f) & 0.001 & 2 & 0.002 & 0.002 & 6 & 0 & 0 & 0 & 6 \\
\hline azoxystrobin (f) & 0.001 & 1 & 0.07 & 0.07 & 3 & 0 & 0 & 0 & 3 \\
\hline benalaxyl (f) & 0.001 & 0 & 0 & 0 & 0.3 & 2 & 0.001 & 0.002 & 0.3 \\
\hline BAC C12 (f) & 0.001 & 0 & 0 & 0 & 0.1 & 1 & 0.005 & 0.005 & 0.1 \\
\hline boscalid (f) & 0.001 & 9 & 0.009 & 1.070 & 5 & 9 & 0.001 & 0.056 & 5 \\
\hline carbendazim (f) & 0.001 & 0 & 0 & 0 & 0.3 & 1 & 0.001 & 0.001 & 0.5 \\
\hline cyhalothrin-lambda (i) & 0.01 & 1 & 0.024 & 0.024 & 0.08 & 0 & 0 & 0 & 0.2 \\
\hline cyprodinil (f) & 0.001 & 4 & 0.010 & 0.300 & 3 & 1 & 0.014 & 0.014 & 3 \\
\hline $\operatorname{DDAC}(\mathrm{f})$ & 0.001 & 1 & 0.028 & 0.028 & 0.1 & 0 & 0 & 0 & 0.1 \\
\hline difenoconazole (f) & 0.001 & 2 & 0.001 & 0.002 & 3 & 0 & 0 & 0 & 3 \\
\hline dimethomorph (f) & 0.001 & 4 & 0.001 & 0.007 & 3 & 6 & 0.001 & 0.009 & 3 \\
\hline famoxadone (f) & 0.002 & 3 & 0.004 & 0.037 & 2 & 0 & 0 & 0 & 2 \\
\hline
\end{tabular}


Table 2. Cont.

\begin{tabular}{|c|c|c|c|c|c|c|c|c|c|}
\hline \multirow[b]{3}{*}{ Analyte $(f / i){ }^{1}$} & \multirow[b]{3}{*}{$\begin{array}{c}\text { LOQ } \\
{[\mathrm{mg} / \mathrm{kg}]}\end{array}$} & \multicolumn{4}{|c|}{ GRAPES } & \multicolumn{4}{|c|}{ WINES } \\
\hline & & \multicolumn{4}{|c|}{ Concentration of Residues [mg/kg] } & \multicolumn{4}{|c|}{ Concentration of Residues [mg/kg] } \\
\hline & & $\mathbf{N}$ & Minimum & Maximum & MRL $^{2}$ & $\mathbf{N}$ & Minimum & Maximum & $\mathrm{MRL}^{3}$ \\
\hline fenhexamid (f) & 0.002 & 4 & 0.101 & 1.110 & 15 & 11 & 0.003 & 0.086 & 15 \\
\hline fenpropidin (f) & 0.001 & 0 & 0 & 0 & 0.01 & 1 & 0.009 & 0.009 & 0.01 \\
\hline fenpyrazamine (f) & 0.001 & 0 & 0 & 0 & 3 & 1 & 0.027 & 0.027 & 3 \\
\hline fludioxonil (f) & 0.001 & 4 & 0.007 & 0.219 & 5 & 1 & 0.001 & 0.001 & 4 \\
\hline fluopicolide (f) & 0.001 & 1 & 0.002 & 0.002 & 2 & 4 & 0.004 & 0.004 & 2 \\
\hline fluopyram (f) & 0.001 & 3 & 0.006 & 0.081 & 1.5 & 6 & 0.001 & 0.023 & 1.5 \\
\hline imidacloprid (i) & 0.001 & 2 & 0.001 & 0.002 & 1 & 0 & 0 & 0 & 1 \\
\hline iprovalicarb (f) & 0.001 & 1 & 0.002 & 0.002 & 2 & 10 & 0.002 & 0.059 & 2 \\
\hline kresoxim-methyl (f) & 0.001 & 2 & 0.001 & 0.002 & 1.5 & 1 & 0.002 & 0.002 & 1.5 \\
\hline mandipropamide (f) & 0.002 & 0 & 0 & 0 & 2 & 2 & 0.002 & 0.002 & 2 \\
\hline mepanipyrim (f) & 0.001 & 2 & 0.001 & 0.001 & 2 & 0 & 0 & 0 & 2 \\
\hline meptyldinocap (f) & 0.001 & 1 & 0.04 & 0.04 & 1 & 0 & 0 & 0 & 1 \\
\hline metalaxyl (f) & 0.001 & 0 & 0 & 0 & 2 & 8 & 0.001 & 0.069 & 1 \\
\hline methoxyfenozide (i) & 0.001 & 1 & 0.024 & 0.024 & 1 & 7 & 0.001 & 0.012 & 1 \\
\hline metrafenone (f) & 0.001 & 0 & 0 & 0 & 7 & 1 & 0.001 & 0.001 & 7 \\
\hline myclobutanil (f) & 0.001 & 3 & 0.002 & 0.012 & 1.5 & 1 & 0.001 & 0.001 & 1.5 \\
\hline paclobutrazole (f) & 0.001 & 0 & 0 & 0 & 0.01 & 1 & 0.002 & 0.002 & 0.01 \\
\hline penconazole (f) & 0.001 & 5 & 0.002 & 0.044 & 0.5 & 0 & 0 & 0 & 0.5 \\
\hline proquinazid (f) & 0.001 & 1 & 0.097 & 0.097 & 0.5 & 0 & 0 & 0 & 0.5 \\
\hline pyraclostrobin (f) & 0.001 & 1 & 0.164 & 0.164 & 1 & 0 & 0 & 0 & 2 \\
\hline pyrimethanil (f) & 0.001 & 5 & 0.002 & 1.440 & 5 & 7 & 0.007 & 0.048 & 5 \\
\hline quinoxyfen (f) & 0.001 & 3 & 0.001 & 0.003 & 1 & 0 & 0 & 0 & 1 \\
\hline spiroxamine (f) & 0.001 & 0 & 0 & 0 & 0.6 & 1 & 0.003 & 0.003 & 0.5 \\
\hline tebuconazole (f) & 0.002 & 3 & 0.002 & 0.034 & 0.5 & 1 & 0.007 & 0.007 & 1 \\
\hline tebufenozide (i) & 0.001 & 0 & 0 & 0 & 4 & 1 & 0.013 & 0.013 & 4 \\
\hline tetraconazole (f) & 0.002 & 1 & 0.002 & 0.002 & 0.5 & 0 & 0 & 0 & 0.5 \\
\hline thiophanate-methyl (f) & 0.001 & 0 & 0 & 0 & 0.1 & 1 & 0.001 & 0.001 & 3 \\
\hline trifloxystrobin (f) & 0.001 & 2 & 0.015 & 0.028 & 3 & 0 & 0 & 0 & 3 \\
\hline
\end{tabular}

${ }^{1}$ (i)—insecticide; (f)—fungicide; ${ }^{2}$ MRLs apply to table grapes (0151010) [23]; ${ }^{3}$ MRLs apply to wine grapes (0151020) [23]. MRL: maximum residue level; LOQ: limit of quantification.

The transfer of pesticide residues from grapes to wines, expressed as processing factor (the ratio of residue levels in processed commodity to those in the raw primary commodity; PF), was influenced by the physicochemical properties of residue (e.g., solubility, $\mathrm{pK}_{\mathrm{ow}}$ ) and technology of the wine-making process (e.g., maceration process of peels in red wine production) [24]. As no legal limits for the concentration of pesticide residues in wines are available, MRL for wine grapes was applied for the evaluation of wines. Nowadays, no harmonized list of PFs is available, therefore, a processing factor of 1 for all quantified pesticide residues was used [25]. However, some available studies show that PFs were fairly lower for a large number of pesticide residues, ranging from $\mathrm{PF}=0.008$ for less polar pesticide, such as ametoctradin, to $\mathrm{PF}=1.6$ for polar pesticide, such as imidacloprid $[10,26,27]$. On this account, it could be presumed, that the contamination of wine grapes was relatively high.

The full results of pesticide residue analysis in tested grapes and wines are detailed in the Supplementary Materials Tables S3 and S4.

\subsection{Pesticide Metabolites in Grapes and Wines from Conventional Production}

In our previous study, the database of 18 metabolites originating from 7 pesticides was established [11]. Here, we aimed to extend pesticide/metabolites list. Based on the results of pesticide residue analyses, an extensive search of particular pesticide metabolic pathways in plants was performed in literature. In addition, common metabolic reac- 
tions were considered when information on metabolism was not available. Both these approaches were combined, resulting in a list of possible metabolites. Subsequently, the LC-HRMS/MS data were searched against the database of the elemental composition of metabolites. The identity of pesticide metabolites, tentatively identified by their calculated quasi-molecular ions (acceptable mass error $\pm 5 \mathrm{ppm}$ ) and the isotopic pattern match, were further confirmed by an interpretation of their fragmentation spectra [11]. Using this approach, the database of pesticide metabolites was extended to 49 compounds originating from 25 pesticides. This database is provided in Table A1 in the Appendix A. All tentatively identified pesticide metabolites were the products of Phase I and Phase II metabolic biotransformation of pesticides taking place in grapevine. Phase I metabolites were identified as the products of hydrolysis (e.g., spiroxamine-N-desethyl; 2,4-DNOP) or oxidation (e.g., fenhexamid-hydroxy; spiroxamine-N-oxide). All detected Phase II pesticide metabolites were the products of conjugation of parent pesticide or Phase I metabolite with hexose (e.g., fenhexamid glycoside; fenhexamid-hydroxy glycoside).

Screening of Pesticide Metabolites in Grapes and Wines from Conventional Production

Since standards of metabolites were not commercially available, determination of metabolite concentrations in tested samples could not be performed. Therefore, the results were presented as "relative response" - the ratio between the area of the detected metabolite and the area of the internal standard (TPP in ESI+ mode, nicarbazin in ESI- mode).

Pesticide metabolites were detected in all tested samples. Altogether, 41 different pesticide metabolites originating from 22 pesticides were found. The metabolite of fenhexamid, fenhexamid-hydroxy, was the most commonly detected biotransformation product in both grapes and wines. Metabolites of iprovalicarb, penconazole, pyrimethanil, cyprodinil and metalaxyl were often found (see Figures 1 and 2), too. Four metabolites of insecticide spirotetramat, which are included in the residue definition (MRL) of spirotetramat, were detected in 3 samples of grapes, while residues of the parent compound were below quantifiable level. In 2 grape samples, no quantifiable residues of fenhexamid were found, but its metabolite, fenhexamid-hydroxy, was detected. Residues of penconazole were frequently detected at concentrations below $0.01 \mathrm{mg} / \mathrm{kg}$, which is commonly tolerated even in organic products; its hydroxylated metabolite was also found in grapes (see Figure 3 for the extracted ion chromatogram of penconazole and its metabolites in grape samples). Similar observations were made for cyprodinil, dimethomorph, fluopyram or mepanipyrim in grapes and for benalaxyl, iprovalicarb, metalaxyl or pyrimethanil in wines.

The full results of the targeted screening of pesticide metabolites in tested grapes and wines are summarized in the Supplementary Materials Tables S3 and S4. 
fenhexamid-hydroxy glycoside fenhexamid-hydroxy penconazole-hydroxy pyrimethanil-hydroxy glucoside penconazole-hydroxy glycoside

cyprodinil-hydroxy glycoside spirotetramat-enol glukosid spirotetramat-enol spirotetramat-mono-hydroxy spirotetramat-keto-hydroxy pyrimethanil-hydroxy fluopyram-hydroxy fenhexamid glycoside cyprodinil-hydroxy trifloxystrobin-demethyl tebuconazole-hydroxy glycoside tebuconazole-hydroxy

dimethomorph-demethyl acetamiprid-desmethyl mepanipyrim-2-hydroxypropyl glycoside mepanipyrim-2-hydroxypropyl pyrimethanil-hydroxy diglucoside pyraclostrobin-hydroxy glycoside

pyraclostrobin-desmethoxy proquinazid-hydroxy glycoside proquinazid-hydroxy methoxyfenozide-hydroxy glycoside iprovalicarb-hydroxy glycoside iprovalicarb-hydroxy fludioxonil-hydroxy glycoside azoxystrobin (Z-isomer) 2,4-DNOP

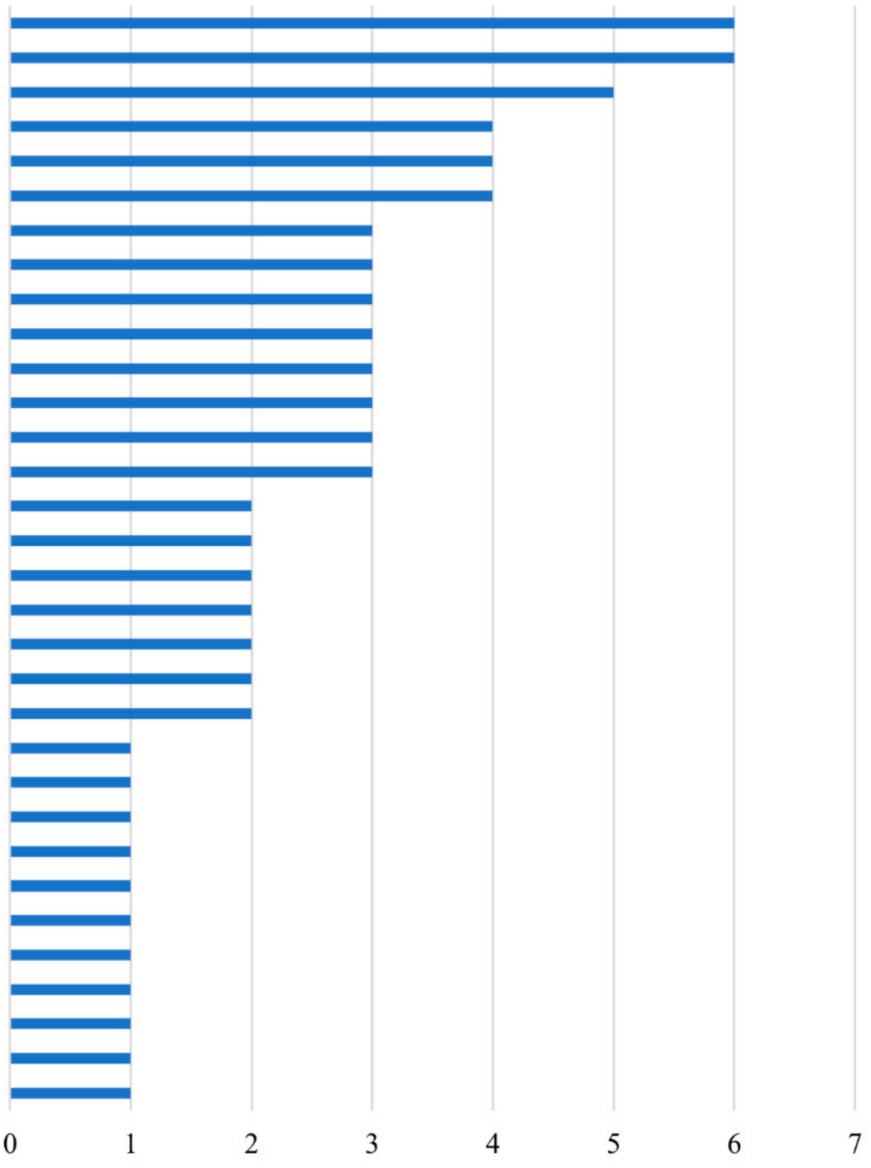

the number of grape samples with detectable pesticide metabolites

fenhexamid-hydroxy iprovalicarb-hydroxy iprovalicarb-hydroxy glycoside pyrimethanil-hydroxy metalaxyl-hydroxy fluopyram-hydroxy tebuconazole-hydroxy glycoside benalaxyl-gluco tebuconazole-hydroxy spiroxamin-N-despropy spiroxamin-N-desethyl pyrimethanil-hydroxy glycoside pyrimethanil-hydroxy diglycoside fenpyrazamine-metabolite fenpropidin-hydroxy cyprodinil-hydroxy glycoside cyprodinil-hydroxy benalaxyl-hydroxy

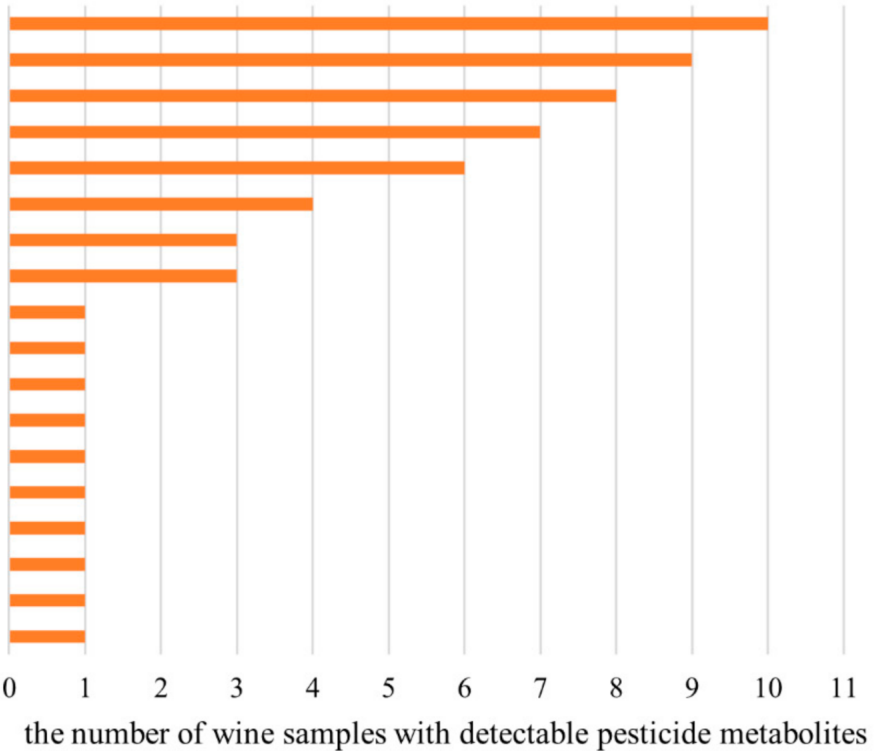

Figure 2. The numbers of grape (total $n=10$ ) and wine (total $n=12$ ) samples from conventional production with detectable pesticide metabolites. 


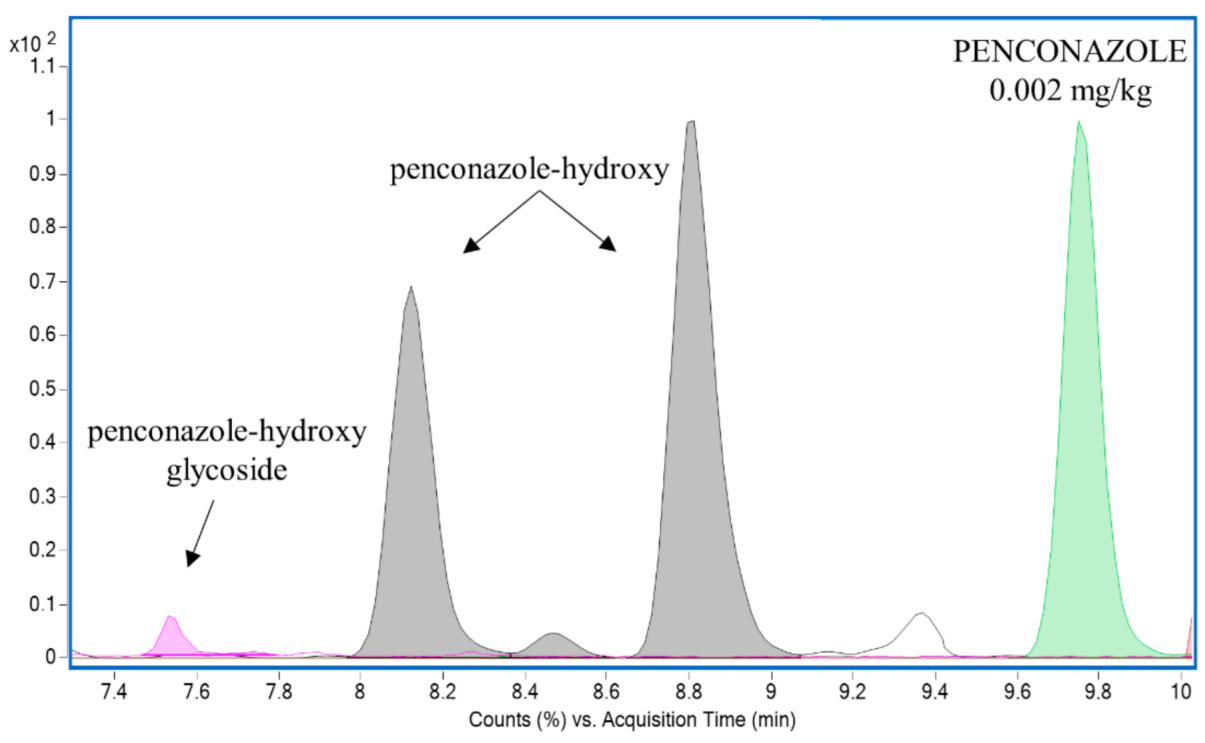

Figure 3. Overlaid extracted ion chromatograms of penconazole $(\mathrm{m} / \mathrm{z} 284.0721)$ and its metabolites penconazole-hydroxy ( $\mathrm{m} / \mathrm{z}$ 300.0665, two isomers) and penconazole-hydroxy glycoside $(\mathrm{m} / \mathrm{z} 462.1176)$ in a grape sample.

\subsection{Screening of Pesticide Residues and Pesticide Metabolites in Grapes and Wines from Organic Production}

The strategy based on combined targeted screening of pesticide residues and their metabolites was applied for authentication of organic products. In this study, 6 organic grape samples and 21 organic wine samples were analyzed for 406 pesticide residues and 49 pesticide metabolites.

In total, 23 out of 27 samples were free of quantifiable residues/detected metabolites or contained residues linked to agricultural practices permitted in organic production (see Figure 4). However, one grape sample contained 13 pesticide residues and 14 metabolites, what documents a fraudulent practice-illegal pesticides use. Residues of spinosad were detected in 3 more samples of grapes; the quantified residue concentrations were, nevertheless, below the MRL, and it is necessary to point out that this active ingredient is approved for organic production. However, three out of 21 wine samples were positively tested for pesticide residues that were not approved in organic production; the quantified concentrations ranged from 0.001 to $0.011 \mathrm{mg} / \mathrm{kg}$. Of screened metabolites, only a metabolite of pyrimethanil (pyrimethanil-hydroxy) was detected in one wine sample, along with a quantifiable residue of the parent pesticide $(0.001 \mathrm{mg} / \mathrm{kg})$. Carbendazim was detected in another sample; it was, however, presumably a degradation product of thiophanate-methyl that was also present in the sample.

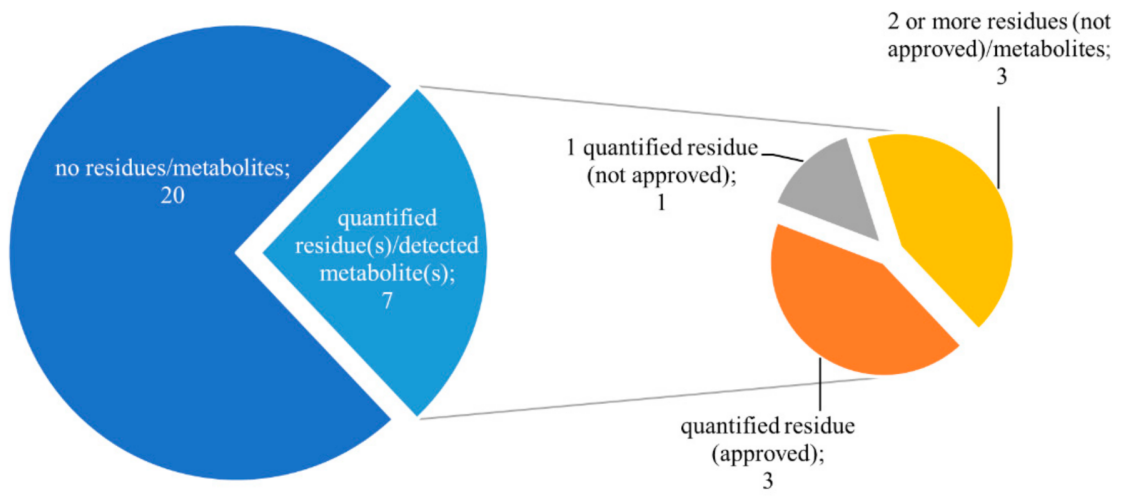

Figure 4. The number of quantified residues/detected metabolites in samples from organic production. 
Considering available PFs for wine production [27], the levels of pesticide residues in wine grapes (raw commodity) probably exceeded the tolerable "limit" for organic production $(0.01 \mathrm{mg} / \mathrm{kg})$. In the third positive sample, the analysis revealed a quantifiable amount $(0.001 \mathrm{mg} / \mathrm{kg})$ of dimethomorph. Detection of pesticide residues (synthetic pesticides) in three wine samples could indicate a potential food fraud; it can, however, also indicate unintentional contamination during the grapevine cultivation or during the wine-making process. Table S5 in the Supplementary Materials summarizes the results of the screening of pesticide residues and pesticide metabolites in organic grapes and wines.

\section{Conclusions}

This study presents the results of the analyses of pesticide residues and metabolites in grapes and wines from both conventional and organic production. Fungicides and insecticides were the most commonly detected pesticide residues; in total, residues of 29 and 25 different pesticides residues were found in grapes and wines, respectively. Screening of pesticide metabolites was performed using the recently extended database of pesticide metabolites containing 49 compounds (representing, in particular, products of hydroxylation and glycosylation). Altogether, 41 different pesticide metabolites originating from 22 pesticides were detected in tested samples. The follow-up research should focus not only on further database extension, but also metabolites quantification in order to estimate the extent of parent compound transformation, hence its original concentration.

Several samples contained no quantifiable residues of parent pesticides (or with their residues below the quantification limit of $0.01 \mathrm{mg} / \mathrm{kg}$ ), while metabolites of such pesticides were unequivocally found. This was observed in the case of cyprodinil, dimethomorph, fenhexamid, fluopyram, mepanipyrim and penconazole in grapes, and benalaxyl, fenhexamid, iprovalicarb, metalaxyl and pyrimethanil in wines.

The control strategy of analyzing pesticide metabolites as markers of unauthorized practices in organic farming was applied to a set of organic samples. In total, $15 \%$ of tested organic samples contained quantifiable residues or detected metabolites. In the latter case (no parent residues detected), such samples would pass a routine residues control without the doubts on their origin when declared as "organic". Our results indicate that the combined analysis of parent pesticides and their metabolites represents a promising tool for tracing history of pesticide application on various crops; moreover, it enables obtaining the evidence on an unauthorized application of plant protection products in organic production.

Supplementary Materials: The following are available online at https:/ /www.mdpi.com/2304-815 8/10/2/307/s1, Table S1: Detailed information of the collected grape and wine samples; Table S2: The list of performance characteristics for all analytes in grapes and wines; Table S3:The full results of pesticide residue analysis and screening of pesticide metabolites in the tested grapes; Table S4: The full results of pesticide residue analysis and screening of pesticide metabolites in the wines; Table S5: The results of the screening of pesticide residues and pesticide metabolites in organic grapes and wines.

Author Contributions: The following authors contributed to this article in the following ways: Conceptualization and methodology, J.P., J.H. and V.K.; formal analysis, D.S.; investigation and resources, D.S. and J.P.; data curation, D.S.; writing—original draft preparation, D.S.; writing—review and editing, J.P., J.H. and V.K.; supervision, project administration and funding acquisition, J.P., J.H. and V.K. All authors have read and agreed to the published version of the manuscript.

Funding: This research was funded by the METROFOOD-CZ research infrastructure project (MEYS Grant No: LM2018100) including the access to its facilities, by the "Operational Programme PragueCompetitiveness" (CZ.2.16/3.1.00/21537 and CZ.2.16/3.1.00/24503) and the "National Programme of Sustainability I"-NPU I LO1601. This work also received support from the EU-China-Safe Horizon 2020 Project (Grant No. 727864).

Data Availability Statement: The data presented in this study are available in the article and the Supplementary Materials. 
Conflicts of Interest: The authors declare no conflict of interest.

\section{Appendix A}

Table A1. The list of pesticide residues and their tentatively identified metabolites.

\begin{tabular}{|c|c|c|c|c|c|c|c|}
\hline$\#$ & $\begin{array}{c}\text { Analyte } \\
\text { (Parent Pesticide/Pesticide } \\
\text { Metabolite) }\end{array}$ & $\begin{array}{l}\text { Elemental } \\
\text { Composition }\end{array}$ & Ion Type & $\begin{array}{l}\text { Detected Ion } \\
\quad\left(\mathrm{MS}^{1}\right)\end{array}$ & $\begin{array}{l}\text { Retention } \\
\text { Time } \\
\text { [min] }\end{array}$ & $\begin{array}{l}\text { Measured } m / z \\
\text { of Fragments } \\
\left(\mathrm{MS}^{2}\right)\end{array}$ & Ref. \\
\hline \multirow{2}{*}{1} & \multirow{2}{*}{ ACETAMIPRID } & \multirow{2}{*}{$\mathrm{C}_{10} \mathrm{H}_{11} \mathrm{ClN}_{4}$} & {$[\mathrm{M}+\mathrm{H}]^{+}$} & 223.0743 & 6.1 & $126.0103 ; 56.0481$ & \multirow{3}{*}{ [28] } \\
\hline & & & {$[\mathrm{M}-\mathrm{H}]^{-}$} & 221.0599 & 6.1 & $140.0268 ; 65.0142$ & \\
\hline $1 \mathrm{a}$ & acetamiprid- $N$-desmethyl & $\mathrm{C}_{9} \mathrm{H}_{9} \mathrm{ClN}_{4}$ & {$[\mathrm{M}+\mathrm{H}]^{+}$} & 209.0589 & 6.0 & $126.0109 ; 56.0481$ & \\
\hline 2 & AZOXYSTROBIN & $\mathrm{C}_{22} \mathrm{H}_{17} \mathrm{~N}_{3} \mathrm{O}_{5}$ & {$[\mathrm{M}+\mathrm{H}]^{+}$} & 404.1241 & 8.8 & $\begin{array}{l}372.0981 ; \\
344.1027 \\
329.0794\end{array}$ & \multirow{2}{*}{ [29] } \\
\hline $2 \mathrm{a}$ & azoxystrobin (Z-isomer) & $\mathrm{C}_{22} \mathrm{H}_{17} \mathrm{~N}_{3} \mathrm{O}_{5}$ & {$[\mathrm{M}+\mathrm{H}]^{+}$} & 404.1241 & 8.5 & $\begin{array}{l}372.0981 ; \\
344.1027 \\
329.0794\end{array}$ & \\
\hline 3 & BENALAXYL & $\mathrm{C}_{20} \mathrm{H}_{23} \mathrm{NO}_{3}$ & {$[\mathrm{M}+\mathrm{H}]^{+}$} & 326.1751 & 9.9 & $\begin{array}{c}208.1333 ; \\
148.1124 ; \\
121.0886 ; 91.0538\end{array}$ & \multirow{3}{*}{ [30] } \\
\hline $3 a$ & benalaxyl-hydroxy & $\mathrm{C}_{20} \mathrm{H}_{23} \mathrm{NO}_{4}$ & {$[\mathrm{M}+\mathrm{H}]^{+}$} & 342.17 & 8.9 & $\begin{array}{l}264.1385 \\
206.1197 \\
164.1095 \\
146.0984\end{array}$ & \\
\hline $3 b$ & benalaxyl-gluco & $\mathrm{C}_{26} \mathrm{H}_{33} \mathrm{NO}_{9}$ & {$[\mathrm{M}+\mathrm{H}]^{+}$} & 504.2228 & 8.4 & $\begin{array}{l}\text { 324.1754; } \\
264.1385 ; \\
206.1197 \\
164.1095 \\
146.0984\end{array}$ & \\
\hline 4 & CYPRODINYL & $\mathrm{C}_{14} \mathrm{H}_{15} \mathrm{~N}_{3}$ & {$[\mathrm{M}+\mathrm{H}]^{+}$} & 226.1339 & 9.7 & $\begin{array}{l}\text { 210.1013; } \\
\text { 185.1082; } \\
\text { 144.0799; } \\
\text { 133.0751; } \\
106.0656\end{array}$ & \multirow{3}{*}{ [31] } \\
\hline $4 a$ & cyprodinyl-hydroxy & $\mathrm{C}_{14} \mathrm{H}_{15} \mathrm{~N}_{3} \mathrm{O}$ & {$[\mathrm{M}+\mathrm{H}]^{+}$} & 242.1288 & $8.7 ; 8.9$ & $\begin{array}{l}\text { 224.1192; } \\
\text { 208.0913; } \\
\text { 142.0629; } \\
124.0732 ; \\
108.0797\end{array}$ & \\
\hline $4 b$ & $\begin{array}{l}\text { cyprodinyl-hydroxy } \\
\text { glykosid }\end{array}$ & $\mathrm{C}_{20} \mathrm{H}_{25} \mathrm{~N}_{3} \mathrm{O}_{6}$ & {$[\mathrm{M}+\mathrm{H}]^{+}$} & 404.1816 & $8.0 ; 8.1 ; 8.7$ & $\begin{array}{l}242.1297 ; \\
224.1192 ; \\
208.0913 ; \\
142.0629 ; \\
124.0732 ; \\
108.0797\end{array}$ & \\
\hline
\end{tabular}


Table A1. Cont.

\begin{tabular}{|c|c|c|c|c|c|c|c|}
\hline$\#$ & $\begin{array}{c}\text { Analyte } \\
\text { (Parent Pesticide/Pesticide } \\
\text { Metabolite) }\end{array}$ & $\begin{array}{l}\text { Elemental } \\
\text { Composition }\end{array}$ & Ion Type & $\begin{array}{l}\text { Detected Ion } \\
\quad\left(\mathrm{MS}^{1}\right)\end{array}$ & $\begin{array}{l}\text { Retention } \\
\text { Time } \\
\text { [min] }\end{array}$ & $\begin{array}{c}\text { Measured } m / z \\
\text { of Fragments } \\
\left(\text { MS }^{2}\right)\end{array}$ & Ref. \\
\hline 5 & DIMETHOMORPH & $\mathrm{C}_{21} \mathrm{H}_{22} \mathrm{ClNO}_{4}$ & {$[\mathrm{M}+\mathrm{H}]^{+}$} & 388.131 & $8.9 ; 9.1$ & $\begin{array}{c}301.0650 ; \\
273.0655 ; \\
165.0541 ; \\
114.0546 ; 70.0271\end{array}$ & \multirow{4}{*}[32]{} \\
\hline $5 a$ & dimethomorph-demethyl & $\mathrm{C}_{20} \mathrm{H}_{20} \mathrm{ClNO}_{4}$ & {$[\mathrm{M}+\mathrm{H}]^{+}$} & 374.1154 & $8.5 ; 8.7$ & $\begin{array}{l}287.048 ; 151.0378 ; \\
114.0546 ; 70.0271\end{array}$ & \\
\hline $5 b$ & $\begin{array}{l}\text { dimethomorph-demethyl } \\
\text { glycoside }\end{array}$ & $\mathrm{C}_{26} \mathrm{H}_{30} \mathrm{ClNO}_{9}$ & {$[\mathrm{M}+\mathrm{H}]^{+}$} & 536.1682 & 7.7 & $\begin{array}{c}374.1154 ; \\
287.0480 ; \\
151.0378 ; 70.0271\end{array}$ & \\
\hline $5 c$ & dimethomorph-hydroxy & $\mathrm{C}_{21} \mathrm{H}_{22} \mathrm{ClNO}_{5}$ & {$[\mathrm{M}+\mathrm{H}]^{+}$} & 404.1259 & $8.1 ; 8.3 ; 8.5$ & $\begin{array}{c}386.1135 ; \\
317.0558 ; \\
289.0614 ; \\
165.0541 ; \\
114.0546 ; 70.0271\end{array}$ & \\
\hline \multirow{2}{*}{6} & \multirow{2}{*}{ FENHEXAMID } & \multirow{2}{*}{$\mathrm{C}_{14} \mathrm{H}_{17} \mathrm{Cl}_{2} \mathrm{NO}_{2}$} & {$[\mathrm{M}+\mathrm{H}]^{+}$} & 302.0709 & 9.4 & $\begin{array}{c}177.9817 ; \\
143.0124 ; 97.1008 ; \\
55.0525\end{array}$ & \multirow{10}{*}{ [33] } \\
\hline & & & {$[\mathrm{M}-\mathrm{H}]^{-}$} & 300.0564 & 9.3 & $\begin{array}{l}264.0796 \\
249.0558 \\
221.0241\end{array}$ & \\
\hline \multirow{2}{*}{$6 a$} & \multirow{2}{*}{ fenhexamid-glycoside } & \multirow{2}{*}{$\mathrm{C}_{20} \mathrm{H}_{27} \mathrm{Cl}_{2} \mathrm{NO}_{7}$} & {$[\mathrm{M}+\mathrm{H}]^{+}$} & 464.1237 & 8.7 & $\begin{array}{c}\text { 302.0702; } \\
177.9817 ; \\
143.0124 ; 97.1008 ; \\
55.0525\end{array}$ & \\
\hline & & & {$[\mathrm{M}-\mathrm{H}]^{-}$} & 462.1082 & 8.6 & $\begin{array}{l}300.0564 ; \\
264.0796 \\
249.0558 \\
221.0241\end{array}$ & \\
\hline \multirow[t]{2}{*}{$6 b$} & \multirow[t]{2}{*}{ fenhexamid-hydroxy } & \multirow[t]{2}{*}{$\mathrm{C}_{14} \mathrm{H}_{17} \mathrm{Cl}_{2} \mathrm{NO}_{3}$} & {$[\mathrm{M}+\mathrm{H}]^{+}$} & 318.0658 & 8.6 & $\begin{array}{c}300.0549 ; \\
175.9651 ; \\
113.0961 ; 97.1008 ; \\
55.0525\end{array}$ & \\
\hline & & & {$[\mathrm{M}-\mathrm{H}]^{-}$} & 316.0513 & 8.5 & $\begin{array}{c}280.073 ; 237.0710 ; \\
175.9663\end{array}$ & \\
\hline \multirow[t]{2}{*}{$6 c$} & \multirow[t]{2}{*}{$\begin{array}{l}\text { fenhexamid-hydroxy } \\
\text { glycoside }\end{array}$} & \multirow[t]{2}{*}{$\mathrm{C}_{20} \mathrm{H}_{27} \mathrm{Cl}_{2} \mathrm{NO}_{8}$} & {$[\mathrm{M}+\mathrm{H}]^{+}$} & 480.1187 & 7.6 & $\begin{array}{c}318.0646 ; \\
300.0549 ; \\
175.9651 ; \\
113.0961 ; 97.1008 ; \\
55.0525\end{array}$ & \\
\hline & & & {$[\mathrm{M}-\mathrm{H}]^{-}$} & 478.1041 & 7.5 & $\begin{array}{c}\text { 316.0497; 280.073; } \\
\text { 237.0710; } \\
175.9663\end{array}$ & \\
\hline \multirow{2}{*}{$6 \mathrm{~d}$} & \multirow{2}{*}{ fenhexamid-dechloro } & \multirow{2}{*}{$\mathrm{C}_{14} \mathrm{H}_{18} \mathrm{ClNO}_{2}$} & {$[\mathrm{M}+\mathrm{H}]^{+}$} & 268.1099 & 9.0 & $\begin{array}{c}232.1335 ; \\
144.0234 ; 97.1012 ; \\
55.0535\end{array}$ & \\
\hline & & & {$[\mathrm{M}-\mathrm{H}]^{-}$} & 266.0975 & 8.9 & $\begin{array}{c}\text { 230.1190; } \\
215.0944 ; 187.004\end{array}$ & \\
\hline
\end{tabular}


Table A1. Cont.

\begin{tabular}{|c|c|c|c|c|c|c|c|}
\hline$\#$ & $\begin{array}{c}\text { Analyte } \\
\text { (Parent Pesticide/Pesticide } \\
\text { Metabolite) }\end{array}$ & $\begin{array}{l}\text { Elemental } \\
\text { Composition }\end{array}$ & Ion Type & $\begin{array}{l}\text { Detected Ion } \\
\left(\mathrm{MS}^{\mathbf{1}}\right)\end{array}$ & $\begin{array}{l}\text { Retention } \\
\text { Time } \\
\text { [min] }\end{array}$ & $\begin{array}{l}\text { Measured } m / z \\
\text { of Fragments } \\
\quad\left(\mathrm{MS}^{2}\right)\end{array}$ & Ref. \\
\hline 7 & FENPROPIDIN & $\mathrm{C}_{19} \mathrm{H}_{31} \mathrm{~N}$ & {$[\mathrm{M}+\mathrm{H}]^{+}$} & 274.2529 & 8.5 & $\begin{array}{c}189.1640 ; \\
147.1165 ; 86.0958 ; \\
57.0687\end{array}$ & \multirow[t]{2}{*}{ [34] } \\
\hline $7 a$ & fenpropidin-hydroxy & $\mathrm{C}_{19} \mathrm{H}_{31} \mathrm{NO}$ & {$[\mathrm{M}+\mathrm{H}]^{+}$} & 290.2478 & 8.1 & $\begin{array}{l}272.2337 \\
147.1165\end{array}$ & \\
\hline 8 & FENPYRAZAMINE & $\mathrm{C}_{17} \mathrm{H}_{21} \mathrm{~N}_{3} \mathrm{O}_{2} \mathrm{~S}$ & {$[\mathrm{M}+\mathrm{H}]^{+}$} & 332.1427 & 9.3 & $\begin{array}{l}304.1461 ; \\
262.0995 ; \\
231.1369 ; \\
230.1289 ; \\
216.1130 ; \\
189.0889 ; \\
145.0750 ; \\
131.0713\end{array}$ & \multirow[t]{2}{*}{ [35] } \\
\hline $8 a$ & fenpyrazamine-metabolite & $\mathrm{C}_{13} \mathrm{H}_{17} \mathrm{~N}_{3} \mathrm{O}$ & {$[\mathrm{M}+\mathrm{H}]^{+}$} & 232.1444 & 6.4 & $\begin{array}{l}190.0971 ; \\
173.0698 \\
145.0750 ; \\
132.0808\end{array}$ & \\
\hline 9 & FLUDIOXONIL & $\mathrm{C}_{12} \mathrm{H}_{6} \mathrm{~F}_{2} \mathrm{~N}_{2} \mathrm{O}_{2}$ & {$[\mathrm{M}-\mathrm{H}]^{-}$} & 247.0325 & 8.9 & $\begin{array}{l}207.0228 ; \\
180.0313 ; \\
169.0391 ; \\
151.0304 ; \\
126.0346\end{array}$ & \multirow[t]{2}{*}{ [36] } \\
\hline $9 a$ & $\begin{array}{l}\text { fludioxonil-hydroxy } \\
\text { glycoside }\end{array}$ & $\mathrm{C}_{18} \mathrm{H}_{16} \mathrm{~F}_{2} \mathrm{~N}_{2} \mathrm{O}_{8}$ & {$[\mathrm{M}-\mathrm{H}]^{-}$} & 425.0802 & 7.1 & $\begin{array}{l}263.0267 ; \\
196.0344 ; \\
126.0346\end{array}$ & \\
\hline 10 & FLUOPYRAM & $\mathrm{C}_{16} \mathrm{H}_{11} \mathrm{ClF}_{6} \mathrm{~N}_{2} \mathrm{O}$ & {$[\mathrm{M}+\mathrm{H}]^{+}$} & 397.0537 & 9.3 & $\begin{array}{l}208.0144 ; \\
190.0486 ; \\
173.0219 ; \\
145.0272\end{array}$ & \multirow[t]{2}{*}{ [37] } \\
\hline $10 \mathrm{a}$ & fluopyram-hydroxy & $\mathrm{C}_{16} \mathrm{H}_{11} \mathrm{ClF}_{6} \mathrm{~N}_{2} \mathrm{O}_{2}$ & {$[\mathrm{M}+\mathrm{H}]^{+}$} & 413.0486 & 8.6 & $\begin{array}{l}395.0370 ; \\
224.0078 ; \\
173.0212 ; \\
145.0272\end{array}$ & \\
\hline \multirow[t]{2}{*}{11} & \multirow[t]{2}{*}{ IPROVALICARB } & \multirow[t]{2}{*}{$\mathrm{C}_{18} \mathrm{H}_{28} \mathrm{~N}_{2} \mathrm{O}_{3}$} & {$[\mathrm{M}+\mathrm{H}]^{+}$} & 321.2173 & 9.4 & $\begin{array}{c}144.0644 ; \\
119.0852 ; \\
116.0700 ; 98.0591 ; \\
91.0533 ; 72.0797 \\
\end{array}$ & \multirow{4}{*}{ [38] } \\
\hline & & & {$\left[\mathrm{M}+\mathrm{CH}_{3} \mathrm{COO}\right]^{-}$} & 319.2027 & 9.3 & $\begin{array}{c}\text { 259.1470; } \\
216.0911 ; 97.0040 ; \\
59.0128\end{array}$ & \\
\hline $11 \mathrm{a}$ & iprovalicarb-hydroxy & $\mathrm{C}_{18} \mathrm{H}_{28} \mathrm{~N}_{2} \mathrm{O}_{4}$ & {$[\mathrm{M}+\mathrm{H}]^{+}$} & 337.2122 & $7.9 ; 8.1$ & $\begin{array}{c}\text { 319.1811; } \\
144.0644 ; \\
135.0800 ; \\
116.0696 ; 98.0591 ; \\
72.0797\end{array}$ & \\
\hline $11 b$ & $\begin{array}{l}\text { iprovalicarb-hydroxy } \\
\text { glycoside }\end{array}$ & $\mathrm{C}_{24} \mathrm{H}_{38} \mathrm{~N}_{2} \mathrm{O}_{9}$ & {$[\mathrm{M}+\mathrm{H}]^{+}$} & 499.265 & $7.3 ; 7.5$ & $\begin{array}{c}337.2099 \\
319.1811 ; \\
144.0644 ; \\
135.0800 \\
116.0696 ; 98.0591 ; \\
72.0797\end{array}$ & \\
\hline
\end{tabular}


Table A1. Cont.

\begin{tabular}{|c|c|c|c|c|c|c|c|}
\hline$\#$ & $\begin{array}{c}\text { Analyte } \\
\text { (Parent Pesticide/Pesticide } \\
\text { Metabolite) }\end{array}$ & $\begin{array}{l}\text { Elemental } \\
\text { Composition }\end{array}$ & Ion Type & $\begin{array}{l}\text { Detected Ion } \\
\quad\left(\mathrm{MS}^{1}\right)\end{array}$ & $\begin{array}{l}\text { Retention } \\
\text { Time } \\
\text { [min] }\end{array}$ & $\begin{array}{l}\text { Measured } m / z \\
\text { of Fragments } \\
\left(\text { MS }^{2}\right)\end{array}$ & Ref. \\
\hline 12 & MEPANIPYRIM & $\mathrm{C}_{14} \mathrm{H}_{13} \mathrm{~N}_{3}$ & {$[\mathrm{M}+\mathrm{H}]^{+}$} & 224.1191 & 9.4 & $\begin{array}{l}207.0937 ; 121.0762 ; \\
106.0639 ; 93.0696\end{array}$ & \multirow{3}{*}{ [39] } \\
\hline $12 \mathrm{a}$ & $\begin{array}{l}\text { mepanipyrim-2- } \\
\text { hydroxypropyl }\end{array}$ & $\mathrm{C}_{14} \mathrm{H}_{17} \mathrm{~N}_{3} \mathrm{O}$ & {$[\mathrm{M}+\mathrm{H}]^{+}$} & 244.1444 & 8.3 & $\begin{array}{c}226.1341 ; \\
200.1181 ; \\
133.0760 ; \\
106.0639 ; 93.0571\end{array}$ & \\
\hline $12 b$ & $\begin{array}{l}\text { mepanipyrim-2- } \\
\text { hydroxypropyl } \\
\text { glycoside }\end{array}$ & $\mathrm{C}_{20} \mathrm{H}_{27} \mathrm{~N}_{3} \mathrm{O}_{6}$ & {$[\mathrm{M}+\mathrm{H}]^{+}$} & 406.1972 & $7.3 ; 7.6$ & $\begin{array}{c}244.1460 ; \\
226.1341 ; \\
200.1181 ; \\
133.0760 ; \\
106.0639 ; 93.0572\end{array}$ & \\
\hline 13 & MEPTYLDINOCAP & $\mathrm{C}_{18} \mathrm{H}_{24} \mathrm{~N}_{2} \mathrm{O}_{6}$ & $\begin{array}{c}{[\mathrm{M}-} \\
\left.\mathrm{C}_{4} \mathrm{H}_{4} \mathrm{O}\right]^{-}\end{array}$ & 295.1299 & 10.9 & $\begin{array}{l}277.2162 ; \\
193.0242 ; \\
171.1023\end{array}$ & \multirow{2}{*}{ [40] } \\
\hline $13 a$ & 2,4-DNOP & $\mathrm{C}_{14} \mathrm{H}_{20} \mathrm{~N}_{2} \mathrm{O}_{5}$ & {$[\mathrm{M}-\mathrm{H}]^{-}$} & 295.1299 & 9.4 & $\begin{array}{l}277.2162 ; \\
193.0242 ; \\
171.1023\end{array}$ & \\
\hline 14 & METALAXYL & $\mathrm{C}_{15} \mathrm{H}_{21} \mathrm{NO}_{4}$ & {$[\mathrm{M}+\mathrm{H}]^{+}$} & 280.1543 & 8.5 & $\begin{array}{c}220.1341 ; \\
192.1397 ; \\
160.1128 ; \\
148.1126 ; 45.0325\end{array}$ & \multirow{2}{*}{ [41] } \\
\hline $14 a$ & metalaxyl-hydroxy & $\mathrm{C}_{15} \mathrm{H}_{21} \mathrm{NO}_{5}$ & {$[\mathrm{M}+\mathrm{H}]^{+}$} & 296.1495 & 8.0 & $\begin{array}{c}278.1361 ; \\
236.1281 ; \\
208.1333 ; \\
176.1075 ; \\
146.0950 ; 45.0325\end{array}$ & \\
\hline 15 & METHOXYFENOZIDE & $\mathrm{C}_{22} \mathrm{H}_{28} \mathrm{~N}_{2} \mathrm{O}_{3}$ & {$[\mathrm{M}-\mathrm{H}]^{-}$} & 369.2174 & 9.1 & $\begin{array}{c}\text { 311.1359; } \\
\text { 149.0602; } \\
121.0647 ; \\
105.0705 ; 80.5643\end{array}$ & \multirow[t]{2}{*}{ [42] } \\
\hline $15 a$ & $\begin{array}{l}\text { methoxyfenozide-hydroxy } \\
\text { glycoside }\end{array}$ & $\mathrm{C}_{28} \mathrm{H}_{38} \mathrm{~N}_{2} \mathrm{O}_{9}$ & {$[\mathrm{M}-\mathrm{H}]^{-}$} & 581.2271 & 7.8 & $\begin{array}{c}327.1369 ; \\
165.0524 ; 96.5673\end{array}$ & \\
\hline 16 & METRAFENONE & $\mathrm{C}_{19} \mathrm{H}_{21} \mathrm{BrO}_{5}$ & {$[\mathrm{M}+\mathrm{H}]^{+}$} & 409.0645 & 10.1 & $\begin{array}{l}226.9706 ; \\
209.0808 ; \\
194.0563 ; \\
166.0626\end{array}$ & \multirow{4}{*}{ [43] } \\
\hline $16 a$ & metrafenone CL 1500836 & $\mathrm{C}_{19} \mathrm{H}_{20} \mathrm{O}_{6}$ & {$[\mathrm{M}+\mathrm{H}]^{+}$} & 345.1333 & 8.5 & $\begin{array}{l}253.0837 ; \\
181.0849 ; \\
165.0545 ; \\
163.0387\end{array}$ & \\
\hline $16 b$ & metrafenone CL 3000402 & $\mathrm{C}_{19} \mathrm{H}_{19} \mathrm{BrO}_{6}$ & {$[\mathrm{M}+\mathrm{H}]^{+}$} & 423.0438 & 9.7 & $\begin{array}{l}393.0310 ; \\
268.1079 ; \\
242.9640 ; \\
240.9500 ; \\
212.9530\end{array}$ & \\
\hline $16 c$ & metrafenone CL 379395 & $\mathrm{C}_{19} \mathrm{H}_{19} \mathrm{BrO}_{6}$ & {$[\mathrm{M}+\mathrm{H}]^{+}$} & 423.0438 & 8.9 & $\begin{array}{l}226.9674 ; \\
225.0758 ; \\
223.0596 ; \\
212.9909 ; \\
195.0648\end{array}$ & \\
\hline
\end{tabular}


Table A1. Cont.

\begin{tabular}{|c|c|c|c|c|c|c|c|}
\hline$\#$ & $\begin{array}{c}\text { Analyte } \\
\text { (Parent Pesticide/Pesticide } \\
\text { Metabolite) }\end{array}$ & $\begin{array}{l}\text { Elemental } \\
\text { Composition }\end{array}$ & Ion Type & $\begin{array}{l}\text { Detected Ion } \\
\quad\left(\mathrm{MS}^{1}\right)\end{array}$ & $\begin{array}{l}\text { Retention } \\
\text { Time } \\
\text { [min] }\end{array}$ & $\begin{array}{c}\text { Measured } m / z \\
\text { of Fragments } \\
\left(\mathrm{MS}^{2}\right)\end{array}$ & Ref. \\
\hline 17 & PENCONAZOLE & $\mathrm{C}_{13} \mathrm{H}_{15} \mathrm{Cl}_{2} \mathrm{~N}_{3}$ & {$[\mathrm{M}+\mathrm{H}]^{+}$} & 284.0721 & 9.8 & $\begin{array}{c}172.9928 ; \\
158.9764 ; 70.0397\end{array}$ & \multirow{3}{*}{ [44] } \\
\hline $17 \mathrm{a}$ & penconazole-hydroxy & $\mathrm{C}_{13} \mathrm{H}_{15} \mathrm{Cl}_{2} \mathrm{~N}_{3} \mathrm{O}$ & {$[\mathrm{M}+\mathrm{H}]^{+}$} & 300.0665 & $8.1 ; 8.8$ & $\begin{array}{c}282.0554 ; \\
213.0225 ; \\
188.9868 ; \\
158.9766 ; 70.0397\end{array}$ & \\
\hline $17 \mathrm{~b}$ & $\begin{array}{l}\text { penconazole-hydroxy } \\
\text { glycoside }\end{array}$ & $\mathrm{C}_{19} \mathrm{H}_{25} \mathrm{Cl}_{2} \mathrm{~N}_{3} \mathrm{O}_{6}$ & {$[\mathrm{M}+\mathrm{H}]^{+}$} & 462.1176 & 7.5 & $\begin{array}{c}\text { 300.0670; } \\
282.0554 ; \\
213.0225 ; \\
188.9868 ; \\
158.9766 ; 70.0397\end{array}$ & \\
\hline 18 & PROQUINAZID & $\mathrm{C}_{14} \mathrm{H}_{17} \mathrm{IN}_{2} \mathrm{O}_{2}$ & {$[\mathrm{M}+\mathrm{H}]^{+}$} & 373.0417 & 10.9 & $\begin{array}{c}330.9943 ; \\
288.9473 ; \\
271.9204 ; \\
162.0431 ; 43.0523\end{array}$ & \multirow{3}{*}{ [45] } \\
\hline $18 \mathrm{a}$ & proquinazid-hydroxy & $\mathrm{C}_{14} \mathrm{H}_{17} \mathrm{IN}_{2} \mathrm{O}_{3}$ & {$[\mathrm{M}+\mathrm{H}]^{+}$} & 389.0352 & 9.9 & $\begin{array}{c}\text { 330.9943; } \\
288.9473 ; \\
271.9204 ; \\
162.0431 ; 59.0480\end{array}$ & \\
\hline $18 \mathrm{~b}$ & $\begin{array}{l}\text { proquinazid-hydroxy } \\
\text { glycoside }\end{array}$ & $\mathrm{C}_{20} \mathrm{H}_{27} \mathrm{IN}_{2} \mathrm{O}_{8}$ & {$[\mathrm{M}+\mathrm{H}]^{+}$} & 551.0844 & 9.2 & $\begin{array}{c}389.0352 ; \\
330.9943 ; \\
288.9473 ; \\
271.9204 ; \\
162.0431 ; 59.0480\end{array}$ & \\
\hline 19 & PYRACLOSTROBIN & $\mathrm{C}_{19} \mathrm{H}_{18} \mathrm{ClN}_{3} \mathrm{O}_{4}$ & {$[\mathrm{M}+\mathrm{H}]^{+}$} & 388.1059 & 9.9 & $\begin{array}{l}324.0523 ; \\
296.0585 ; \\
194.0811 ; \\
163.0628 ; \\
149.0468 ; \\
133.0517\end{array}$ & \multirow{5}{*}{ [46] } \\
\hline \multirow[t]{2}{*}{$19 a$} & \multirow[t]{2}{*}{ pyraclostrobin-hydroxy } & \multirow[t]{2}{*}{$\mathrm{C}_{19} \mathrm{H}_{18} \mathrm{ClN}_{3} \mathrm{O}_{5}$} & {$[\mathrm{M}+\mathrm{H}]^{+}$} & 404.1008 & 9.9 & $\begin{array}{l}312.0469 ; \\
194.0811 ; \\
163.0628 ; \\
149.0468 ; \\
133.0517\end{array}$ & \\
\hline & & & {$[\mathrm{M}-\mathrm{H}]^{-}$} & 402.0862 & 9.9 & $\begin{array}{l}208.0045 ; \\
164.0134 ; \\
157.0006\end{array}$ & \\
\hline $19 b$ & pyraclostrobin-desmethoxy & $\mathrm{C}_{18} \mathrm{H}_{16} \mathrm{ClN}_{3} \mathrm{O}_{3}$ & {$[\mathrm{M}+\mathrm{H}]^{+}$} & 358.0953 & 9.9 & $\begin{array}{l}326.0677 ; \\
298.0585 ; \\
164.0704 ; \\
132.0434\end{array}$ & \\
\hline $19 \mathrm{c}$ & $\begin{array}{l}\text { pyraclostrobin-hydroxy } \\
\text { glycoside }\end{array}$ & $\mathrm{C}_{25} \mathrm{H}_{28} \mathrm{ClN}_{3} \mathrm{O}_{10}$ & {$[\mathrm{M}+\mathrm{H}]^{+}$} & 566.1536 & 8.6 & $\begin{array}{l}\text { 404.1008; } \\
\text { 312.0469; } \\
\text { 194.0811; } \\
\text { 163.0628; } \\
\text { 149.0468; } \\
133.0517\end{array}$ & \\
\hline
\end{tabular}


Table A1. Cont.

\begin{tabular}{|c|c|c|c|c|c|c|c|}
\hline$\#$ & $\begin{array}{c}\text { Analyte } \\
\text { (Parent Pesticide/Pesticide } \\
\text { Metabolite) }\end{array}$ & $\begin{array}{l}\text { Elemental } \\
\text { Composition }\end{array}$ & Ion Type & $\begin{array}{l}\text { Detected Ion } \\
\quad\left(\mathrm{MS}^{1}\right)\end{array}$ & $\begin{array}{l}\text { Retention } \\
\text { Time } \\
\text { [min] }\end{array}$ & $\begin{array}{c}\text { Measured } m / z \\
\text { of Fragments } \\
\left(\mathrm{MS}^{2}\right)\end{array}$ & Ref. \\
\hline 20 & PYRIMETHANIL & $\mathrm{C}_{12} \mathrm{H}_{13} \mathrm{~N}_{3}$ & {$[\mathrm{M}+\mathrm{H}]^{+}$} & 200.1183 & 8.8 & $\begin{array}{c}183.0927 ; \\
143.0608 ; \\
107.0614 ; 82.0656\end{array}$ & \multirow{4}{*}{ [47] } \\
\hline $20 \mathrm{a}$ & pyrimethanil-hydroxy & $\mathrm{C}_{12} \mathrm{H}_{13} \mathrm{~N}_{3} \mathrm{O}$ & {$[\mathrm{M}+\mathrm{H}]^{+}$} & 216.113 & $7.3 ; 7.6 ; 8.0$ & $\begin{array}{c}198.1035 ; \\
183.0979 ; \\
159.0545 ; \\
107.0609 ; 82.0654\end{array}$ & \\
\hline $20 \mathrm{~b}$ & $\begin{array}{l}\text { pyrimethanil-hydroxy } \\
\text { glycoside }\end{array}$ & $\mathrm{C}_{18} \mathrm{H}_{23} \mathrm{~N}_{3} \mathrm{O}_{6}$ & {$[\mathrm{M}+\mathrm{H}]^{+}$} & 378.1661 & 6.9 & $\begin{array}{c}216.1148 ; \\
198.1035 ; \\
183.0979 ; \\
159.0545 ; \\
107.0609 ; 82.0654\end{array}$ & \\
\hline $20 c$ & $\begin{array}{c}\text { pyrimethanil-hydroxy } \\
\text { diglycoside }\end{array}$ & $\mathrm{C}_{23} \mathrm{H}_{31} \mathrm{~N}_{3} \mathrm{O}_{10}$ & {$[\mathrm{M}+\mathrm{H}]^{+}$} & 510.2082 & 6.6 & $\begin{array}{c}378.1673 ; \\
216.1148 ; \\
198.1035 ; \\
183.0979 ; \\
159.0545 ; \\
107.0609 ; 82.0654\end{array}$ & \\
\hline 21 & SPIROTETRAMAT & $\mathrm{C}_{21} \mathrm{H}_{27} \mathrm{NO}_{5}$ & {$[\mathrm{M}+\mathrm{H}]^{+}$} & 374.1961 & 9.4 & $\begin{array}{l}330.2062 ; \\
302.1740 ; \\
270.1484 ; \\
244.1330 ; \\
216.1006 ; \\
124.0726\end{array}$ & \multirow{9}{*}{ [48] } \\
\hline $21 \mathrm{a}$ & Spirotetramat-enol & $\mathrm{C}_{18} \mathrm{H}_{23} \mathrm{NO}_{3}$ & {$[\mathrm{M}+\mathrm{H}]^{+}$} & 302.1751 & 8.1 & $\begin{array}{l}270.1487 \\
216.1006 \\
124.0726\end{array}$ & \\
\hline $21 b$ & $\begin{array}{l}\text { Spirotetramat-enol } \\
\text { glucoside }\end{array}$ & $\mathrm{C}_{24} \mathrm{H}_{33} \mathrm{NO}_{8}$ & {$[\mathrm{M}+\mathrm{H}]^{+}$} & 464.2278 & $5.2 ; 5.6$ & $\begin{array}{l}302.1739 \\
270.1487 \\
216.1006 \\
124.0726\end{array}$ & \\
\hline $21 c$ & $\begin{array}{c}\text { Spirotetramat } \\
\text { BYI08330-cis-keto-hydroxy }\end{array}$ & $\mathrm{C}_{18} \mathrm{H}_{23} \mathrm{NO}_{4}$ & {$[\mathrm{M}+\mathrm{H}]^{+}$} & 318.17 & 8.5 & $\begin{array}{l}300.1618 \\
268.1335 \\
214.0869\end{array}$ & \\
\hline $21 d$ & $\begin{array}{l}\text { Spirotetramat } \\
\text { BYI08330-mono-hydroxy }\end{array}$ & $\mathrm{C}_{18} \mathrm{H}_{25} \mathrm{NO}_{3}$ & {$[\mathrm{M}+\mathrm{H}]^{+}$} & 304.1907 & 7.6 & $\begin{array}{l}272.1647 \\
21101512\end{array}$ & \\
\hline 22 & SPIROXAMINE & $\mathrm{C}_{18} \mathrm{H}_{35} \mathrm{NO}_{2}$ & {$[\mathrm{M}+\mathrm{H}]^{+}$} & 298.2741 & 8.9 & $\begin{array}{c}144.1345 ; \\
100.1083 ; 72.0795\end{array}$ & \\
\hline $22 a$ & spiroxamine- $N$-oxide & $\mathrm{C}_{18} \mathrm{H}_{35} \mathrm{NO}_{3}$ & {$[\mathrm{M}+\mathrm{H}]^{+}$} & 314.269 & $9.0 ; 9.2 ; 9.3$ & $\begin{array}{c}160.1328 ; \\
130.1218 ; \\
100.1112 ; 88.0750\end{array}$ & \\
\hline $22 \mathrm{~b}$ & spiroxamine- $N$-desethyl & $\mathrm{C}_{16} \mathrm{H}_{31} \mathrm{NO}_{2}$ & {$[\mathrm{M}+\mathrm{H}]^{+}$} & 270.2428 & 8.7 & $116.1066 ; 72.0810$ & \\
\hline $22 \mathrm{c}$ & spiroxamine- $N$-despropyl & $\mathrm{C}_{15} \mathrm{H}_{29} \mathrm{NO}_{2}$ & {$[\mathrm{M}+\mathrm{H}]^{+}$} & 256.2271 & 8.4 & $\begin{array}{c}102.0909 ; 84.0797 \\
58.0639\end{array}$ & \\
\hline
\end{tabular}


Table A1. Cont.

\begin{tabular}{|c|c|c|c|c|c|c|c|}
\hline$\#$ & $\begin{array}{c}\text { Analyte } \\
\text { (Parent Pesticide/Pesticide } \\
\text { Metabolite) }\end{array}$ & $\begin{array}{l}\text { Elemental } \\
\text { Composition }\end{array}$ & Ion Type & $\begin{array}{l}\text { Detected Ion } \\
\quad\left(\mathrm{MS}^{1}\right)\end{array}$ & $\begin{array}{l}\text { Retention } \\
\text { Time } \\
\text { [min] }\end{array}$ & $\begin{array}{c}\text { Measured } m / z \\
\text { of Fragments } \\
\left(\mathrm{MS}^{2}\right)\end{array}$ & Ref. \\
\hline \multirow[t]{2}{*}{23} & \multirow[t]{2}{*}{ TEBUCONAZOLE } & \multirow[t]{2}{*}{$\mathrm{C}_{16} \mathrm{H}_{22} \mathrm{ClN}_{3} \mathrm{O}$} & {$[\mathrm{M}+\mathrm{H}]^{+}$} & 308.1524 & 9.8 & $\begin{array}{c}151.0312 ; \\
139.0285 ; \\
125.0147 ; 70.0390 ; \\
57.0704\end{array}$ & \multirow{5}{*}{ [50] } \\
\hline & & & {$[\mathrm{M}-\mathrm{H}]^{-}$} & 306.1379 & 9.7 & $\begin{array}{c}223.0911 ; 82.0407 ; \\
68.0255\end{array}$ & \\
\hline \multirow{2}{*}{$23 a$} & \multirow{2}{*}{ tebuconazole-hydroxy } & \multirow{2}{*}{$\mathrm{C}_{16} \mathrm{H}_{22} \mathrm{ClN}_{3} \mathrm{O}_{2}$} & {$[\mathrm{M}+\mathrm{H}]^{+}$} & 324.1473 & $8.9,9.4 ; 9.7$ & $\begin{array}{c}141.0078 ; \\
125.0147 ; 70.0390\end{array}$ & \\
\hline & & & {$[\mathrm{M}-\mathrm{H}]^{-}$} & 322.1334 & $9.2 ; 9.5$ & $\begin{array}{c}239.0838 ; \\
223.0911 ; 68.0255\end{array}$ & \\
\hline $23 b$ & $\begin{array}{l}\text { tebuconazole-hydroxy } \\
\text { glycoside }\end{array}$ & $\mathrm{C}_{22} \mathrm{H}_{32} \mathrm{ClN}_{3} \mathrm{O}_{7}$ & {$[\mathrm{M}+\mathrm{H}]^{+}$} & 486.2002 & 8.4 & $\begin{array}{c}324.1481 ; \\
141.0078 ; \\
125.0147 ; 70.0390\end{array}$ & \\
\hline 24 & TEBUFENPYRAD & $\mathrm{C}_{18} \mathrm{H}_{24} \mathrm{ClN}_{3} \mathrm{O}$ & {$[\mathrm{M}+\mathrm{H}]^{+}$} & 334.1681 & 10.3 & $\begin{array}{l}200.0584 ; \\
171.0322 ; \\
147.0532 ; \\
145.0540 ; \\
132.0938 ; \\
117.0223\end{array}$ & \multirow[t]{2}{*}{ [51] } \\
\hline $24 a$ & tebufenpyrad-hydroxy & $\mathrm{C}_{18} \mathrm{H}_{24} \mathrm{ClN}_{3} \mathrm{O}_{2}$ & {$[\mathrm{M}+\mathrm{H}]^{+}$} & 350.163 & 9.1 & $\begin{array}{l}\text { 200.0584; } \\
171.0323 ; \\
163.1109 ; \\
145.1007 ; \\
133.1017\end{array}$ & \\
\hline 25 & TRIFLOXYSTROBIN & $\mathrm{C}_{20} \mathrm{H}_{19} \mathrm{~F}_{3} \mathrm{~N}_{2} \mathrm{O}_{4}$ & {$[\mathrm{M}+\mathrm{H}]^{+}$} & 409.1370 & 10.1 & $\begin{array}{l}206.0813 ; \\
186.0535 ; \\
162.0917 ; \\
146.0608 ; \\
131.0730\end{array}$ & \multirow{3}{*}{ [52] } \\
\hline $25 a$ & trifloxystrobin isomers & $\mathrm{C}_{20} \mathrm{H}_{19} \mathrm{~F}_{3} \mathrm{~N}_{2} \mathrm{O}_{4}$ & {$[\mathrm{M}+\mathrm{H}]^{+}$} & 409.1370 & $\begin{array}{l}9.9 ; 10.3 ; \\
10.5\end{array}$ & $\begin{array}{l}206.0813 ; \\
186.0535 ; \\
162.0917 ; \\
146.0608 ; \\
131.0730\end{array}$ & \\
\hline $25 b$ & trifloxystrobin-demethyl & $\mathrm{C}_{19} \mathrm{H}_{17} \mathrm{~F}_{3} \mathrm{~N}_{2} \mathrm{O}_{4}$ & {$[\mathrm{M}+\mathrm{H}]^{+}$} & 395.1213 & $9.3+9.6$ & $\begin{array}{l}192.0800 ; \\
186.0537 ; \\
148.0762 ; \\
116.0498\end{array}$ & \\
\hline
\end{tabular}

\section{References}

1. Food and Agriculture Organisation. Table and Dried Grapes. Available online: Http:/ /Www.Fao.Org/3/a-I7042e.Pdf (accessed on 13 July 2020).

2. Grimalt, S.; Dehouck, P. Review of Analytical Methods for the Determination of Pesticide Residues in Grapes. J. Chromatogr. A 2016, 143, 1-23. [CrossRef]

3. Phytosanitary Portal (Rostlinolékařský Portál). Central Institute for Supervising and Testing in Agriculture (UKZUZ). Available online: http:/ / eagri.cz/public/app/srs_pub/fytoportal/fy-public/?k=0\#rlp I met:domu | kap1:uvod I kap:uvod (accessed on 12 December 2020).

4. Heshmati, A.; Nili-Ahmadabadi, A.; Rahimi, A.; Vahidinia, A.; Taheri, M. Dissipation Behavior and Risk Assessment of Fungicide and Insecticide Residues in Grape under Open-Field, Storage and Washing Conditions. J. Clean. Prod. 2020, $270,122287$. [CrossRef] 
5. EFSA; Medina-Pastor, P.; Triacchini, G. The 2018 European Union Report on Pesticide Residues in Food. Efsa J. $2020,18,6057$. [CrossRef]

6. European Food Safety Authority. The 2015 European Union Report on Pesticide Residues in Food. Efsa J. 2017, 15, e04791. [CrossRef]

7. European Commission. Organic Farming. Available online: Https://Ec.Europa.Eu/Info/Food-Farming-Fisheries/Farming/ Organic-Farming_en (accessed on 23 January 2021).

8. Rahman, S.M.E.; Mele, M.A.; Lee, Y.-T.; Islam, M.Z. Consumer Preference, Quality, and Safety of Organic and Conventional Fresh Fruits, Vegetables, and Cereals. Foods 2021, 10, 105. [CrossRef]

9. EC. Commission Regulation (EC) No 889/2008 of 5 September 2008 Laying down Detailed Rules for the Implementation of Council Regulation (EC) No 834/2007 on Organic Production and Labelling of Organic Products with Regard to Organic Production, Labelling and Control (consolidated text). Off. J. Eur. Union 2008, L 250, 1-84.

10. Hou, X.; Xu, Z.; Zhao, Y.; Liu, D. Rapid Analysis and Residue Evaluation of Six Fungicides in Grape Wine-Making and Drying. J. Food Compos. Anal. 2020, 89, 103465. [CrossRef]

11. Schusterova, D.; Suchanova, M.; Pulkrabova, J.; Kocourek, V.; Urban, J.; Hajslova, J. Can Occurrence of Pesticide Metabolites Detected in Crops Provide the Evidence on Illegal Practices in Organic Farming? J. Agr. Food Chem. 2019, 67, 6102-6115. [CrossRef] [PubMed]

12. Skidmore, M.W.; Benner, J.P.; Chun Lam, C.C.; Booth, J.D.; Clark, T.; Gledhill, A.J.; Roberts, K.J. Bioavailability of Common Conjugates and Bound Residues. In Pesticide Chemistry; Ohkawa, H., Miyagawa, H., Lee, P.W., Eds.; Wiley-VCH Verlag GmbH \& Co. KGaA: Weinheim, Germany, 2007; pp. 383-393. ISBN 978-3-527-61124-9.

13. Bauer, A.; Luetjohann, J.; Rohn, S.; Jantzen, E.; Kuballa, J. Development of a Suspect Screening Strategy for Pesticide Metabolites in Fruit and Vegetables by UPLC-Q-Tof-MS. Food Anal. Methods 2018, 11, 1591-1607. [CrossRef]

14. Hu, M.; Tan, H.; Li, Y.; Qiu, J.; Liu, L.; Zeng, D. Simultaneous Determination of Tiafenacil and Its Six Metabolites in Fruits Using Ultra-High-Performance Liquid Chromatography/Tandem Mass Spectrometry. Food Chem. 2020, 327, 127015. [CrossRef]

15. Chen, X.; Dong, F.; Xu, J.; Liu, X.; Wu, X.; Zheng, Y. Effective Monitoring of Fluxapyroxad and Its Three Biologically Active Metabolites in Vegetables, Fruits, and Cereals by Optimized QuEChERS Treatment Based on UPLC-MS/MS. J. Agric. Food Chem. 2016, 64, 8935-8943. [CrossRef]

16. Mekonnen, T.F.; Byrne, L.; Panne, U.; Koch, M. Investigation of Chlorpyrifos and Its Transformation Products in Fruits and Spices by Combining Electrochemistry and Liquid Chromatography Coupled to Tandem Mass Spectrometry. Food Anal. Methods 2018, 11, 2657-2665. [CrossRef]

17. Yang, M.; Luo, F.; Zhang, X.; Zhou, L.; Lou, Z.; Zhao, M.; Chen, Z. Dissipation and Risk Assessment of Multiresidual Fungicides in Grapes under Field Conditions. J. Agric. Food Chem. 2020, 68, 1071-1078. [CrossRef]

18. Castro, G.; Pérez-Mayán, L.; Carpinteiro, I.; Ramil, M.; Cela, R.; Rodríguez, I. Residues of Anilinopyrimidine Fungicides and Suspected Metabolites in Wine Samples. J. Chromatogr. A 2020, 1622, 461104. [CrossRef]

19. Berset, J.D.; Mermer, S.; Robel, A.E.; Walton, V.M.; Chien, M.L.; Field, J.A. Direct Residue Analysis of Systemic Insecticides and Some of Their Relevant Metabolites in Wines by Liquid Chromatography-Mass Spectrometry. J. Chromatogr. A 2017, 1506, 45-54. [CrossRef]

20. Bletsou, A.A.; Jeon, J.; Hollender, J.; Archontaki, E.; Thomaidis, N.S. Targeted and Non-Targeted Liquid Chromatography-Mass Spectrometric Workflows for Identification of Transformation Products of Emerging Pollutants in the Aquatic Environment. Trac Trends Anal. Chem. 2015, 66, 32-44. [CrossRef]

21. Polgár, L.; García-Reyes, J.F.; Fodor, P.; Gyepes, A.; Dernovics, M.; Abrankó, L.; Gilbert-López, B.; Molina-Díaz, A. Retrospective Screening of Relevant Pesticide Metabolites in Food Using Liquid Chromatography High Resolution Mass Spectrometry and Accurate-Mass Databases of Parent Molecules and Diagnostic Fragment Ions. J. Chromatogr. A 2012, 1249, 83-91. [CrossRef]

22. European Commission. Guidance Document on Analytical Quality Control and Method Validation Procedures for Pesticide Residues and Analysis in Food and Feed; SANTE/12682/2019; DG SANTE: Bruxelles, Belgium, 2019.

23. Regulation (EC) No 396/2005 of the European Parliament and of the Council of 23 February 2005 on Maximum Residue Levels of Pesticides in or on Food and Feed of Plant and Animal Origin and Amending Council Directive 91/414/EEC 2020 (consolidated text). Off. J. Eur. Union 2005, L 70, 1-16.

24. Kaushik, G.; Satya, S.; Naik, S.N. Food Processing a Tool to Pesticide Residue Dissipation-A Review. Food Res. Int. 2009, 42, 26-40. [CrossRef]

25. European Food Safety Authority. The 2016 European Union Report on Pesticide Residues in Food. Efsa J. 2018, 16, e05348. [CrossRef]

26. Pazzirota, T.; Martin, L.; Mezcua, M.; Ferrer, C.; Fernandez-Alba, A.R. Processing Factor for a Selected Group of Pesticides in a Wine-Making Process: Distribution of Pesticides during Grape Processing. Food Addit. Contam. Part A 2013, 30, 1752-1760. [CrossRef]

27. Scholz, R.; van Donkersgoed, G.; Herrmann, M.; Kittelmann, A.; von Schledorn, M.; Graven, C.; Mahieu, K.; van der Velde-Koerts, T.; Anagnostopoulos, C.; Bempelou, E.; et al. Database of Processing Techniques and Processing Factors Compatible with the EFSA Food Classification and Description System FoodEx 2 Objective 3: European Database of Processing Factors for Pesticides in Food. EFS3 2018, 15. [CrossRef] 
28. European Food Safety Authority. Review of the Existing Maximum Residue Levels (MRLs) for Acetamiprid According to Article 12 of Regulation (EC) No 396/2005. Efsa J. 2011, 9, 2328. [CrossRef]

29. European Food Safety Authority. Reasoned Opinion on the Review of the Existing Maximum Residue Levels (MRLs) for Azoxystrobin According to Article 12 of Regulation (EC) No 396/2005. Efsa J. 2013, 11, 3497. [CrossRef]

30. European Food Safety Authority. Reasoned Opinion on the Review of the Existing Maximum Residue Levels (MRLs) for Benalaxyl According to Article 12 of Regulation (EC) No 396/2005. Efsa J. 2013, 11, 3405. [CrossRef]

31. European Food Safety Authority. Reasoned Opinion on the Review of the Existing Maximum Residue Levels (MRLs) for Cyprodinil According to Article 12 of Regulation (EC) No 396/2005. Efsa J. 2013, 11, 3406. [CrossRef]

32. European Food Safety Authority. Modification of the Existing MRLs for Dimethomorph in Various Crops. Efsa J. 2010, 8, 1622. [CrossRef]

33. Food and Agriculture Organisation. Pesticide Residues in Food-2005: Fenhexamid. Available online: Http:/ /Www.Fao.Org/ Fileadmin/Templates/Agphome/Documents/Pests_Pesticides/JMPR/JMPR05report.Pdf (accessed on 13 July 2020).

34. European Food Safety Authority. Conclusion Regarding the Peer Review of the Pesticide Risk Assessment of the Active Substance Fenpropidin. Efsa J. 2008, 6, 124r. [CrossRef]

35. European Food Safety Authority. Reasoned Opinion on the Modification of the Existing MRLs for Fenpyrazamine in Almonds, Grapes, Apricots, Peaches and Strawberries. Efsa J. 2012, 10, 2989. [CrossRef]

36. European Food Safety Authority. Conclusion Regarding the Peer Review of the Pesticide Risk Assessment of the Active Substance Fludioxonil. Efsa J. 2007, 5, 110r. [CrossRef]

37. Food and Agriculture Organisation. Pesticide Residues in Food-2010: Fluopyram. Available online: Http:/ /Www.Fao.Org/ Fileadmin/Templates/Agphome/Documents/Pests_Pesticides/JMPR/Evaluation10/Fluopyram.Pdf (accessed on 13 July 2020).

38. European Food Safety Authority. Conclusion on the Peer Review of the Pesticide Risk Assessment of the Active Substance Iprovalicarb. Efsa J. 2015, 13, 4060. [CrossRef]

39. European Food Safety Authority. Review of the Existing Maximum Residue Levels (MRLs) for Mepanipyrim According to Article 12 of Regulation (EC) No 396/2005. Efsa J. 2011, 9, 2342. [CrossRef]

40. European Food Safety Authority. Review of the Existing Maximum Residue Levels (MRLs) for Dinocap According to Article 12 of Regulation (EC) No 396/2005. Efsa J. 2011, 9, 2340. [CrossRef]

41. European Food Safety Authority. Review of the Existing Maximum Residue Levels (MRLs) for Metalaxyl-M According to Article 12 of Regulation (EC) No 396/2005. Efsa J. 2011, 9, 2494. [CrossRef]

42. Food and Agriculture Organisation. Pesticide Residues in Food-2003: Methoxyfenozide. Available online: Http:/ /Www.Fao Org/Fileadmin/Templates/Agphome/Documents/Pests_Pesticides/JMPR/Evaluation03/Methoxyfenozide_2003.Pdf (accessed on 13 July 2020).

43. European Food Safety Authority. Modification of the Existing MRLs for Metrafenone in Table and Wine Grapes. Efsa J. 2011, 9, 1979. [CrossRef]

44. EFSA; Brancato, A.; Brocca, D.; De Lentdecker, C.; Erdos, Z.; Ferreira, L.; Greco, L.; Jarrah, S.; Kardassi, D.; Leuschner, R.; et al. Modification of the Existing Maximum Residue Level for Penconazole in Grapes. Efsa J. 2017, 15, e04768. [CrossRef]

45. European Food Safety Authority. Conclusion on the Peer Review of the Pesticide Risk Assessment of the Active Substance Proquinazid. Efsa J. 2009, 7, 1350. [CrossRef]

46. Food and Agriculture Organisation. Pesticide Residues in Food-2004: Pyraclostrobin. Available online: Http:/ /Www.Fao.Org/ Fileadmin/Templates / Agphome/Documents/Pests_Pesticides/JMPR/Evaluation04/Pyraclostrobinaf.Pdf (accessed on 13 July 2020).

47. Food and Agriculture Organisation. Pesticide Residues in Food-2007: Pyrimethanil. Available online: Http:/ /Www.Fao.Org/ Fileadmin/Templates/Agphome/Documents/Pests_Pesticides/JMPR/Evaluation07/Pyrimethanil.Pdf (accessed on 13 July 2020).

48. European Food Safety Authority. Reasoned Opinion on the Modification of the Existing MRLs for Spirotetramat in Strawberries, Bananas, Table Olives, Pineapples and Shallots. Efsa J. 2013, 11, 3361. [CrossRef]

49. European Food Safety Authority. Conclusion on the Peer Review of the Pesticide Risk Assessment of the Active Substance Spiroxamine. Efsa J. 2010, 8, 1719. [CrossRef]

50. European Food Safety Authority. Conclusion on the Peer Review of the Pesticide Risk Assessment of the Active Substance Tebuconazole. Efsa J. 2014, 12, 3485. [CrossRef]

51. European Food Safety Authority. Conclusion Regarding the Peer Review of the Pesticide Risk Assessment of the Active Substance Tebufenpyrad. Efsa J. 2009, 7, 192r. [CrossRef]

52. Food and Agriculture Organisation. Pesticide Residues in Food-2004: Trifloxystrobin. Available online: Http://Www.Fao.Org/ Fileadmin/Templates/Agphome/Documents/Pests_Pesticides/JMPR/Evaluation04/TRIFLOXYSTROBIN.Pdf (accessed on 13 July 2020). 